\title{
Convergence, Crisis and Unemployment in Europe: The Need for Innovative Policies
}

\author{
Enrico Marelli \\ Department of Economics and Management, University of \\ Brescia, Italy \\ enrico.marelli@unibs.it
}

\section{Marcello Signorelli}

Department of Economics, University of Perugia, Italy marcello.signorelli@unipg.it

\author{
CroEconSur \\ Vol. 17 \\ No. 2 \\ December 2015 \\ pp. $5-56$
}

Received: July 30, 2015

Accepted: November 11, 2015

Research Article

doi:10.15179/ces.17.2.1

\section{Abstract}

The paper reviews the double crisis that affected the euro area in the recent period. The focal point is that the austerity measures that have been undertaken in the area, especially in the peripheral countries hurt by the sovereign debt crisis, have not only caused a deep recession but are likely to lead to stagnation and persistent unemployment.

In the first part of the paper, original weaknesses in the construction of the monetary union are examined, the emphasis being placed on nominal convergence criteria without taking into account the need for real convergence. This analysis is corroborated by some econometric investigations based on sigma and beta convergence for different macroeconomic variables, distinguishing between the pre-crisis period, 1999-2007, and the recent 2008-2013 period. The empirical section continues with a discussion of recent macroeconomic trends focusing on 
unemployment: it stresses that the deep and prolonged recession can be defeated only by adequate demand management policies.

The next section explains how the excessive austerity policies recently carried out have also been caused by wrong assumptions about the size of the fiscal multipliers. The final policy section emphasizes three aspects: (i) the radical reforms, at the European level, necessary if the monetary union is to survive; (ii) the changes in macroeconomic policies required to put an end to the present stagnation; (iii) the different and innovative policies needed to fight the high level of unemployment (especially youth unemployment).

Keywords: convergence, crisis, unemployment, eurozone, EU policies

JEL classification: O47, J69, O52, E60

\section{Introduction ${ }^{1}$}

More than fifty years have elapsed since the creation of the European Community, then European Union (EU): the project was grand and it ensured economic progress, peace and prosperity. ${ }^{2}$ More than fifteen years have passed since the birth of the euro. In the first ten years (1999-2008) the monetary union guaranteed an overall macroeconomic stability, low inflation rates - also in countries previously affected by an inflation-prone behavior - and stillness in financial markets: the interest rates were almost identical in the whole eurozone.

The shock of the Global Financial Crisis (2007-2008) and Global Recession (2008-2009) dramatically changed the situation. The initial impact on EU countries was similar to what occurred in the United States and other advanced

1 Earlier versions of this paper were presented at the 16th INFER Annual Conference (28-31 May 2014, Pescara, Italy), at the 13th EACES Biennial Conference (4-6 September 2014, Budapest, Hungary), at the 55th Meeting of Società Italiana degli Economisti (23-25 October 2014, Trento, Italy), at the 1st Workshop (Youth) Unemployment in Europe (16-17 April 2015, Frankfurt-Oder, Germany), the 1st World Congress of Comparative Economics (Rome, 25-27 June 2015).

2 Eminent achievements realized within half a century led in 2012 to the award of the Nobel Peace Prize to the EU. For this introduction we refer to the account in Marelli and Signorelli (2015). 
economies. However, the following sovereign debt crisis (2010-2014) has caused a "double-dip" recession in many eurozone countries, producing a long-lasting impact on real economies - especially in the form of the growing and persistent unemployment - and triggered off severe social and even political consequences. ${ }^{3}$

The recent economic evolution after the eurozone crisis has revealed some crucial weaknesses in the original construction of the Economic and Monetary Union (EMU): in Section 2 we shall emphasize how such construction fails to match the well-known requisites of standard economic theories, e.g., the "optimum currency area" theories. In Section 3 there will be an account of the events that, having commenced with the Global Financial Crisis and passing through the Great Recession, culminated in the sovereign debt crisis: we shall consider both innovations introduced in the EU governance (the EFSF and ESM funds, the non-conventional measures of the ECB, etc.) and also the mistakes and delays of the EU policies. A brief account of the macroeconomic evolution (following euro's introduction) in the EU and in the eurozone, with an application of the sigma and beta convergence approaches, will be presented in Section 4. In this section we also analyze more recent macroeconomic trends, with particular reference to unemployment.

In Section 5 there will be a critical appraisal of the policies adopted by the EU institutions and governments, especially the widespread austerity measures. Consequences of such policies shall also be emphasized, in particular the "selfdefeating" effects of fiscal consolidation. Finally, in Section 6 we shall focus on: (i) the radical reforms needed at the European level for a viable Economic and Monetary Union; (ii) the macroeconomic policies required to put an end to the present stagnation; (iii) the innovative policies needed to fight the high level of unemployment (especially youth unemployment).

3 "Eurosceptic" movements have proliferated throughout Europe, as confirmed by the outcome of the recent elections to the European Parliament (May 2014). 


\section{The Original Weaknesses in the Construction of the Economic and Monetary Union}

The integration process in the EU has been wide-ranging and deep, although not always continuous and coherent over time. The EU has enlarged from a community of six in 1958 to a community of 28 in 2013, encompassing now most of the countries on the continent. Regarding the deepening aspect, the initial Common Market and Customs Union (realized between 1958 and 1968) were completed by the Single Market, focusing on the "four" liberalisations (goods, services, capitals and people), launched in 1985 and to be achieved by 1992. The more ambitious subsequent step, the European Economic and Monetary Union (EMU), was the key goal of the Maastricht Treaty (1992), to be established in $1999^{4}$.

The EMU is officially viewed as an instrument to achieve "economic and social progress, a high level of employment, balanced and sustainable development" (as stated in Article 2 of the Treaty). This should lead in the long run to a "real" convergence, i.e., a convergence in economic performances of individual member States. It implies the narrowing of differences in the structural conditions of different countries (and regions), thus allowing achievement of similar performances of the real variables as well as catching-up of the backward countries and regions (in terms of the standard of living, productivity, etc).

On the contrary, a short-run view of real convergence stresses that economic convergence is rather a prerequisite to accomplish an effective monetary union. The literature on "optimum currency areas" (OCA) is here pertinent: real convergence, for instance in economic structures, rendering more symmetric the economic shocks, makes the exchange rate instrument unnecessary and raises the net benefits of EMU. If shocks are more symmetric across countries, then real variables tend to respond more similarly: this outcome can be evaluated, for example, considering the degree of synchronisation of business cycles between 4 An intermediate step toward the monetary union is represented by the Exchange Rate Mechanism (ERM) of the European Monetary System (EMS), launched in 1979; after the big crisis of 1992-93, it still formally survives as ERM-II, for the countries waiting to join the eurozone. 
countries. The adjustment after shocks would be easier in the presence of an adequate degree of flexibility in prices and wages, high labor mobility and an ample centralized public budget.

A key question is whether real convergence is likely to increase or decrease with the integration process. A first view, purported by Krugman (1993), is that economic integration is likely to deliver increasing specialisation, diverging economic structures, asymmetric developments, and widening differences in growth rates. An opposite, more optimistic, view (initially offered by Eichengreen, 1993), states that the degree of similarity of economic systems is enhanced by increased competition and integration of markets; for example, in the $\mathrm{EU}^{5}$ it may be the outcome of the Single Market, the liberalisation of capital flows and the working of EMU itself. At the empirical level, many studies have shown that synchronicity has increased not only in the European "core", but also in a wider area including some "peripheral" countries and even some New Member States (NMS). ${ }^{6}$

The Maastricht Treaty has, on the contrary, stressed the nominal convergence as a pre-condition for candidate countries to enter the EMU. The well-known convergence criteria (on inflation, interest rate, exchange rate, public deficit and debt) were, for the first time, verified in 1998, allowing to define a list of eleven members that in January 1999 gave birth to EMU, that now comprises nineteen members. ${ }^{7}$ Since 1999 the European Central Bank (ECB) has been responsible for the conduct of monetary policy in the eurozone; at the top of its final aims there is the price stability: the current specification of this target is an inflation rate slightly below but close to 2 percent.

5 In the case of EU integration, the link has been from EU's institutional integration to trade deepening and then to cycle correlation. Notice that the "endogeneity of OCA's criteria" proposition maintains that it is the creation of a monetary union itself that leads not only to trade integration but also to structural convergence (see the empirical contributions of Frankel and Rose, 1998, and Rose, 2000).

6 See the review in Marelli and Signorelli (2010a). This study includes an investigation of real convergence in its multifaceted features (per capita income, productivity, labor market and industry indicators, trade links, business cycle behavior, etc.), including its relation with nominal and institutional convergence.

7 The following countries joined in the subsequent years: Greece (2001), Slovenia (2007), Cyprus and Malta (2008), Slovakia (2009), Estonia (2011), Latvia (2014), and Lithuania (2015) 
Also after the start of EMU, EU members had to satisfy nominal criteria concerning fiscal policy and public budgets, as specified in the Growth and Stability Pact (GSP): the public deficit cannot exceed 3 percent of GDP, apart from exceptional circumstances, and in the medium run the public budget should reach a balanced situation. The GSP was reformed in 2005, increasing the flexibility and discretion in the application of the sanctions; such a reform was also the consequence of the 2002-2003 budget difficulties of Germany and France (together with the decision not to apply sanctions in autumn 2004). As a matter of fact, not one country has ever been sanctioned despite several occurrences of "excessive deficits".

Why has the causality between real convergence and nominal convergence upheld by OCA's theories been reversed in the Maastricht strategy? From the EU Commission point of view the nominal convergence ${ }^{8}$, through macroeconomic stability (price stability and fiscal discipline), removal of the exchange-rate risk, reduction of uncertainty (concerning inflation and interest rates), favors investment and international trade, eventually leading to stronger economic growth. ' In particular, for the formerly "deviating" countries ${ }^{10}$ there were expectations that they could be rewarded by the gains of EMU itself: disinflation, lower interest rates and debt service; these gains should be added to the general benefits of monetary unions (in terms of lower transaction costs, lesser uncertainty, reinforced competition, etc.). On the other hand, we know that the same countries have suffered consequences because their economic growth has been impaired by the stringency of the nominal conditions. ${ }^{11}$

The strategy adopted by the Maastricht Treaty has been criticized by many authors precisely because of the possible negative short-run impact on the real

8 The justification for nominal convergence criteria has been critically assessed by many authors (e.g., Buiter, 2004; De Grauwe and Schanbl, 2005).

9 Buti and Sapir (1998).

10 In this way, those countries were punished for their previous "vices": undisciplined public finances, inflationprone behavior, etc. (with the ultimate threat of being left out of EMU).

11 It should be added that the "bonus" due to lower interest rates has not been used by all countries to stimulate - also through accompanying structural reforms - higher economic growth and/or to improve public account sustainability (in countries with high debt levels). 
economic growth caused by the deflationary effects of restrictive monetary and fiscal policies undertaken by several countries at the same time (e.g., De Grauwe, 2007). As a matter of fact, the same EU institutions realized, after 1999, that novel attention should be given to the problems of the growing and persistent unemployment: the institutional response to these problems was the Lisbon Agenda of 2000, followed by the more recent "Europe 2020" plan adopted in 2010. Nevertheless, the quantitative targets that were proposed (e.g., concerning employment rates) were mere benchmarks, much softer than the Maastricht or GSP criteria. As a consequence, economic growth has been lower in Europe throughout the new century, even before the recent financial crisis, if compared to other leading economies in the world ${ }^{12}$ : China, India, most of the emerging countries, but also the United States. ${ }^{13}$

An even greater problem is that economic growth has not been uniform within the EU and even the eurozone. Overall, a certain degree of convergence has been insured by the catching-up of the New Member States (NMS) of Central and Eastern Europe. ${ }^{14}$ Nevertheless, some old members (e.g., Italy and Portugal) exhibited very low growth rates; in particular, productivity growth was very weak in many countries, also because of the slow pace of structural reforms. ${ }^{15}$ Furthermore, many peripheral countries - the two mentioned countries but also Spain and Greece - were suffering because of an increasing competitiveness gap. ${ }^{16}$ Without the possibility to devalue the national currencies, the trade and

12 See Table A1 in the Appendix.

13 Nominal stability and convergence have instead been satisfactory in the pre-crisis period: e.g., the inflation rate has been, for a period of about ten years, very close to the 2 percent target, even in the countries that in the ' 90 s used to exhibit much higher inflation.

14 The specific trends of transition countries are reviewed in Marelli and Signorelli (2010b).

15 Alesina, Ardagna and Galasso (2011) have found that the adoption of the euro has been associated with an acceleration of the pace of structural reforms in the product markets (deregulations), but not in the case of labor markets.

16 In the decade since 1999, the real exchange rate based on unit labor costs depreciated by about 10 percent in Germany and appreciated by 10-15 percent in Italy and Spain. An account of the balance of payments' problems of the peripheral countries of the eurozone can be found in Higgins and Klitgaard (2014). According to Seminerio (2012), Germany became more competitive in the early years of this century also thanks to the labor market and welfare reforms, accompanied however by a temporary loss of the fiscal discipline (as shown by the excessive deficit in 2003). 
current account deficits have been rising, being the counterpart of the surpluses of Germany and the other "core" EU countries.

\section{The Dual Crisis that Struck the European Countries}

The recent financial crisis originated outside Europe, in the United States, but then reached the worst and lasting consequences in the eurozone. The subprime crisis originated in 2007-2008 in the US: in the previous years, the monetary policy was expansionary till the mid of the decade, thus encouraging consumer credit, loans, mortgages (also to "subprime" debtors) and causing the mounting of financial and housing bubbles. Then it suddenly became more restrictive, triggering off the explosion of such bubbles and the consequent crisis of several banks that went bankrupt or were bailed out by the governments. The instability soon propagated to the global financial system because of high leverage, massive securitization, and diffusion of derivatives and toxic assets. In addition, the Lehman Brothers crack determined a dramatic fall in confidence, with immediate effects on the financial markets (stock indices, interest rates, etc.). The real effects were caused by the credit crunch, the negative wealth effects (due to the fall in equities and bonds), adverse expectations and systemic uncertainty. ${ }^{17}$

From the fall of 2008 to the first half of 2009 the production, income, investment, consumption, and world trade collapsed: the so-called "Great Recession" has been the deepest contraction in economic activity since the Great Depression of the '30s (Imbs, 2010). The recession propagated to Europe and to many world countries, although China, India and other emerging economies just witnessed a deceleration in their growth rates; the biggest falls in GDP were not recorded in the financial centres (US and Great Britain) but in the main manufacturing and exporting countries ( -5 percent in Germany, -5.5 percent in Italy and Japan).

17 The historical experiences on financial and debt crises are investigated by Reinhart and Rogoff $(2009,2011)$. For the developments in the eurozone, see EC (2012); an interesting comparison with the crisis in Argentina is in Frenkel (2013). 
The labor market impact has been delayed, as usual: in normal recessions unemployment reaches the top value 18 months after the start of the recession and the lag is even longer in the case of financial crises (see IMF, 2010); however, it was differentiated across countries. Unemployment rate rapidly increased in the most flexible countries, e.g., in the US, the UK, Ireland, the Baltic states and Spain (in the latter case because of the high incidence of temporary contracts). In countries characterised by less flexible labor markets or by "internal" flexibilities (such as working hour adjustments or other instances of labor hoarding), such as Germany, the increase has been narrow or null..$^{18}$

In 2009, at the peak of the Great Recession, there were some fears about the risks of a prolonged depression or a "double-dip" recession ${ }^{19}$, but recovery began in the US that very summer and propagated, although at a much slower pace, to Europe (nevertheless the rate of growth in the leading country, Germany, was above 3 percent in 2010-2011). The recovery was facilitated by the economic policy response in many world countries which was strong and manifold, thus differentiating this response from the policy mistakes made during the Great Depression of the '30s. It comprised, in the US and in many EU countries: (i) wide rescue plans of banks (the most relevant ones have been adopted in the US, the UK, Ireland and Spain); (ii) accommodating monetary policies: interest rates were lowered to almost zero in many countries and were accompanied by "unconventional" operations of liquidity management (e.g., the "quantitative easing" in the US); (iii) expansionary fiscal policies (in addition to the working of automatic stabilizers). On the contrary, despite several proposals from international institutions and agencies (such as the G-20 group) the reform of the international financial system has shown little progress.

Public budgets on the other hand deteriorated not only because of the recession and the rescue of banks, but also as a consequence of the fiscal stimulus packages

18 See Table 4 below. In the case of Italy the initial impact on unemployment has been small both because of the Cassa Integrazione Guadagni (CIG)'s buffer and due to the discouraged workers effect; but the unemployment rate rose continuously in the following five years.

19 See Roubini (2010). 
(see Coenen et al., 2012, among others). These caused an increase in the ratios of deficit/GDP ${ }^{20}$ and debt/GDP ${ }^{21}$, already rising because of the fall in GDP itself. This deterioration in the fiscal stance of many countries caused a new instability scenario that was unveiling in the Old Continent. The situation precipitated because of some news coming from Greece. In October 2009 the new Greek government (Papandreou) revealed that the true deficit/GDP ratio was equal to 12 percent, double than previously announced (then further revised upward by Eurostat). ${ }^{22}$

The real deterioration of the fiscal stance in many eurozone countries and the news about the falsification of accounts in Greece, determined an abrupt drop in confidence of the financial markets. The spread in the rate of interest on public debt, compared to the German bonds, began to increase, initially in Greece and subsequently in the other peripheral countries, the so-called "Piigs" (Portugal, Ireland, Italy, Greece and Spain). The credit default swaps on sovereign debt deteriorated as well, also because of the downgrade progressively decided by the rating agencies (Moody's, Standard \& Poor's and Fitch), that in some cases anticipated market trends but in some others ratified dynamics already in progress.

The crisis changed the perception of the risk compared to the previous decade, when the euro was considered irreversible and the default of a member country highly unlikely (in fact spreads on Italian bonds compared to the German "bund", for instance, had been for many years after the advent of the euro around 20 or 30 basis points). The high spread levels encountered from 2010-2011 were

20 From 2007 to 2009 these ratios increased as follows: from 2.8-11.9 percent in the US, 2.1-8.8 percent in Japan, 2.7-11.5 percent in the UK, 0.7-6.3 percent in the eurozone; we mention also the changes in individual countries: 0-14 percent in Ireland, 6.5-15.6 percent in Greece, from surplus to 11.2 percent in Spain, 3.1-10.2 percent in Portugal, 1.6-5.4 percent in Italy.

21 The debt/GDP ratios augmented in the 2007-2012 period as follows: from 66.3 percent to 93.1 percent in the eurozone (but also from 44.4 percent to 89.8 percent in the UK); the individual variations are: 107.4-161.6 percent in Greece, 103.1-127.1 percent in Italy, 24.8-117.2 percent in Ireland, 68.3-120.6 percent in Portugal, 36.288.4 percent in Spain, 64.2-90.3 percent in France, 65.2-81.6 percent in Germany. See also the Tables in the Appendix.

22 It should be mentioned that Greece formally respected the 3 percent threshold for the deficit/GDP ratio - in order to join the EMU in 2001 - by producing fake data (as disclosed only after euro circulation in the country). 
due not only to the perception of the risk of default (i.e., the inability to repay the debt as a function of national progresses in the actions of fiscal consolidation), but also due to the one related to the possibility of some countries abandoning the eurozone or even the very existence of the euro: for the first time since its birth markets were beginning to question the irreversibility of the common currency.

Consequently, the contagion spread from Greece to other peripheral countries. Despite several similarities - in terms of financial vulnerability - there are also significant differences between the "Piigs". Public deficits have strongly increased in most of them, but not in Italy; on the other hand, in the latter country the initial public debt was much higher than in the remaining countries. Moreover, private debt was extremely high in Ireland and Spain, where the banking and housing bubbles caused dramatic crises in such sectors; in Italy it was much lower. Finally, prior to the crisis, economic growth was strong in Greece, Spain and (above all) Ireland, while it was feeble in Portugal and almost nil in Italy. ${ }^{23}$

The uncertain, delayed and inadequate economic policy response also contributed to the contagion in the eurozone. In the spring of 2010, when it was clear that Greece could not save itself, the interventions were postponed not only for legal problems (the no bail-out clause included in the Maastricht Treaty) or economic ones (moral hazard problem), but also for political reasons (the political situation in Germany advised to postpone any decision until the completion of elections in some German Länders). Some measures were taken in May 2010: bilateral loans to Greece, settlement of the European Financial Stability Facility (EFSF), purchase of sovereign bonds on the secondary market by the ECB (through the SMP, Securities Market Program), but they were not sufficient to contrast the speculative attacks. These were partly determined by the EU Council decision to make private owners responsible for the losses in case of default or restructuring of the debt. ${ }^{24}$ 
As a consequence, the contagion reached Ireland and Portugal, that were helped through the EFSF in autumn 2010 and spring 2011 respectively. Then, in the summer 2011 the speculative attacks turned against Spain and, especially, Italy. ${ }^{25}$ Notice that Spain and even more Italy are too big to bail out (because of the size of their public debts), but also too big to default: their defaulting would almost certainly imply the collapse of EMU. A temporary cooling of spreads was facilitated by the operations of the SMP of ECB, addressed also in favor of Italy and Spain, and continued until the end of the year.

The situation did not improve even after the institution of a new permanent fund (the European Stability Mechanism, ESM) ${ }^{26}$ and the adoption of the Fiscal Compact for the eurozone countries, i.e., stricter rules, compared to the previous GSP, that in future a balanced budget and the reduction of public debt in relation to GDP should be guaranteed. Only after ECB President Draghi's declaration (summer 2012) "we shall save euro whatever it takes" and the consequent adoption of the "Outright Monetary Transactions" (OMT) plan ${ }^{27}$ the situation began to improve. Thus, despite some risks and sources of instability, thanks to the fiscal adjustment efforts in individual countries and to the stronger commitment by EU institutions (at least the ECB), the financial situation partially improved since the end of 2012 and the systemic risk reached low levels in the following years.

The negative impact of the EU policies is in any case troublesome. The strict austerity measures, added to the uncertainty created by the same systemic sovereign debt crisis, have resulted in a new recession ${ }^{28}$ : policy-makers seemed to

25 The spread on Italian bonds was higher than the Spanish one for about half a year, from August 2011 to February 2012; in fact, the budget decided following the joint letter of the ECB and the Bank of Italy in August was not enough to reverse the expectations about the sustainability of the debt. The spread reached a top value of 575 basis points in November 2011; this dreadful financial instability was one of the reasons for the change in the Government. The new Monti Government soon adopted austerity measures such as the "Save Italy" law, including a major reform of the pension system.

26 On the relations between these two funds, see Schäfer (2012).

27 The purchase of sovereign bonds was conditional upon the acceptance of strict fiscal consolidation plan. The plan was envisaged to reduce the "excessive" spread (i.e., the part related to the euro's breakup risk); so the ECB was willing to purchase, on secondary markets, unlimited amounts of sovereign bonds. The plan received a provisional approval by the German Constitutional Court that deferred the final decision to the EU Justice Court, whose response was ultimately positive.

28 The double-dip recession (De Grauwe, 2012), in the European countries with generalized falls of GDP in 20122013, also contributed to the new global economic slowdown, assimilated by Krugman (2012) to a true depression. 
overlook the fact that public deficits and debts were not the cause of the financial crisis, but rather its consequence. ${ }^{29}$ In addition, this recession raised up again the debt/GDP ratios and made more difficult the reduction of the deficit /GDP ratio (see Tables A2 and A3 in the Appendix); i.e., austerity was self-defeating (see Section 5). The miraculous virtues of the so-called "expansionary austerity" have not been found ${ }^{30}$ and the real economies are suffering precisely because of the austerity measures undertaken in the Piigs countries and in the eurozone as a whole. While social pain is soaring, citizens, especially in the Piigs, feel that sacrifices do not deliver the promised results (Wyplosz, 2012a).

In general, we can say that EU policies have been either delayed or inadequate, being characterized - as stressed by many authors - by a "too little too late" approach. The monetary policy of the ECB has finally become sufficiently accommodative, especially after the decisions in 2014 (the adoption of the "targeted long term refinancing operations", the lowering of the key interest rate to 0.05 percent in November and the application of negative rates to short-term deposits) and early 2015 (the adoption of the "quantitative easing"). However, such decisions, on one side, have been forced by the new deflationary scenario (-0.3 percent was the inflation rate in the eurozone in February 2015) and, on the other side, are not probably enough to stimulate in a decisive way the real economy (similar decisions were taken by the FED in the US five years earlier, soon after the Great Recession, when the likely impact was highest).

As to the fiscal stance, it has not substantially changed. The request to exclude public investments from the deficit definition in the GSP has been substantially rejected; some "flexibilities" have been introduced only in the co-financing of the EU structural funds. The "Juncker Plan" to stimulate public and private investment in the EU has been a first move in the right direction, but the resources still seem too limited (as we shall explain in Section 6).

29 The recent macroeconomic trends are clear: unlike the US, the growth in the entire 2009-2013 period was negative in the EU (-1.2 percent yearly rate), with deep contractions in the Piigs: Greece ( -5.1 percent per year), Italy and Portugal (-1.5 percent), Spain (-1.4 percent) and Ireland ( -1 percent); see also Table A1 in the Appendix.

30 Even the financial markets now seem to penalize countries for the feeble growth prospects rather than for temporary deviations from positions of a balanced budget. 


\section{Macroeconomic Convergence in the EU and the Impact of the Crisis}

In this section, we first analyze economic convergence in the EU, particularly in the eurozone, focusing on real variables and nominal variables; then we discuss the economic impact of the double crisis affecting the eurozone countries, with particular reference to unemployment.

\subsection{Sigma and Beta Convergence in the EU}

When analyzing the long-run convergence (after the introduction of the euro) in the EU (and eurozone) countries, we have followed both the simple "sigma convergence" approach, by investigating the evolution over time of some dispersion measures ${ }^{31}$ of the relevant variables, and the "beta convergence" approach (this type of analysis is well established in literature: see Barro and Sala-I-Martin, 1995).

The sigma convergence refers both to "real" economic variables (GDP per capita, unemployment rate, long run unemployment rate) and to "nominal" variables (such as debt/GDP ratio, deficit/GDP ratio, primary balance/GDP ratio, interest payments/GDP ratio). Our analysis refers to the EU countries (for the period 1995-2012 or 2013) and to the eurozone countries (1999-2012). See the Figures A1 - A7 in the Appendix, Source: Eurostat.

With reference to GDP per capita (Figure A1), the dispersion in the EU obviously increased after the 2004 enlargement; then it remained more or less stable. On the contrary, in the eurozone it slightly increased from 1999 to 2007 and again in 2010-2011. Taking into consideration the unemployment rate (Figure A2) we find a decreasing dispersion 2000-2007, then an increasing trend. A similar pattern is shown, in the case of the eurozone, by the long term unemployment

31 The coefficient of variation, i.e., the standard deviation divided by the mean, is normally used as dispersion measure; but the standard deviation itself is used for the variables in which positive and negative numbers alternate over time (Coeff. of Var. or St. Dev. is specified on the figures in the Appendix). 
dispersion (Figure A3), that before the crisis was slower in comparison with the full EU group.

With reference to the nominal variables, the dispersion of debt/GDP ratios (Figure A4) slightly increased in the eurozone before the crisis, but the deterioration was even worse in the EU. After the crisis, the dispersion to some extent decreased in both areas: in fact, as we know, the debt has increased everywhere, also in the previously "good" countries. The dispersion in deficit/GDP and primary balancel GDP ratios (Figures A5 and A6) presents similar dynamics, with a peak in 2010, followed by a "re-adjustment" to be noticed in the last two years. Finally, the interest/GDP ratios dispersion (Figure A7) shows a more stable situation in the EU compared to the eurozone, apart from 2011 (the year when the sovereign debt crisis exploded).

Considering now the beta-convergence approach, we refer to the absolute convergence, e.g., investigating whether GDP per capita (or other variables) of different countries are converging to a unique level. ${ }^{32}$ The regression can be specified as follows ( $i$ is the individual country):

$1 / n \ln \left(Y_{i t} / Y_{i 0}\right)=\alpha+\beta \ln \left(Y_{i 0}\right)+\varepsilon$

where $Y$ is GDP per capita, 0 is the initial year, $t$ the final year and $n$ represents the number of years from 0 to $\mathrm{t}$ (and $l n$ stands for natural logarithm). If the estimated coefficient $\beta$ is negative and significant there is absolute convergence.

We estimated this regression considering, first of all, GDP per capita for the countries within the eurozone in 2014 (i.e., there were 18 observations for the whole period) ${ }^{33}$, by distinguishing between the pre-crisis period (1999-2007) and the crisis period (2008-2012). The results are shown in Table 1. We can see that the clear beta-convergence detected in the 1999-2007 period (the coefficient is

32 For a conditional beta-convergence analysis, see our previous study (Marelli and Signorelli, 2010a), where the reference period was 1992-2006 (thus not considering the crisis period). We remark that the econometric estimations in this Section aim at offering a general idea of the convergence or divergence trends in specific macroeconomic variables, rather than providing a thorough account of the forces underlying convergence or divergence.

33 This choice was made also in order to have an acceptable number of observations (18) for our regressions. 
significant at 1 percent level) disappears during the crisis (the coefficient is still negative but not significant anymore).

Table 1: Absolute Beta Convergence in GDP Per Capita (1999-2007 and 2008-2012)

\begin{tabular}{l|c|c|c|c}
\cline { 2 - 5 } & \multicolumn{2}{c|}{ Eurozone 18 } & EU 15 & EU 27 \\
\cline { 2 - 5 } Period & $1999-2007$ & $2008-2012$ & $1995-2007$ & $2008-2012$ \\
\hline No. obs. & 18 & 18 & 15 & 27 \\
\hline Beta coefficient & $\mathbf{- 0 . 0 3 5 * * *}$ & $\mathbf{- 0 . 0 0 8}$ & $\mathbf{- 0 . 0 0 7}$ & $\mathbf{- 0 . 0 2 3 ^ { * * }}$ \\
\hline Adj. R2 & 0.466 & -0.035 & 0.052 & 0.185 \\
\hline
\end{tabular}

Significance levels: 1 percent ${ }^{* *}, 5$ percent ${ }^{* *}, 10$ percent ${ }^{*}$; constant not reported

A possible explanation is that nominal convergence - euro adoption and the satisfaction of Maastricht's criteria - led to a better real integration of eurozone countries, consistently with the "endogeneity of OCA's criteria" proposition (briefly mentioned in Section 2). An alternative explanation is that the euro area comprises also countries (e.g., in Eastern Europe) that are still in their catchingup process, thus exhibiting higher growth rates. Notice that the regression was made considering the total sample of 18 countries since 1999; this can explain why this outcome of beta convergence is different from the already commented (slight) sigma divergence found for the period until 2007 (Figure A1).

In order to make a comparison, we repeated the regression for the EU aggregates, either EU-15 for the 1995-2007 period ${ }^{34}$ or EU-27 for the 2008-2012 period. In fact, it might be that some convergence was caused by integration of real economies (customs union, single market, etc.), independently from the adoption of a common currency. However, our results (Table 1) show that in these wider areas there was a significant convergence only in the crisis period (not before), probably because the crisis made an impact also on some previously rich countries.

34 The EU-27 aggregate was not considered for this period because it is less significant (many countries joined the EU in 2004 or 2007 ). 
Regression (similar to the previous equation), with unemployment rate instead of GDP per capita, provided the results shown in Table 2. For the eurozone, there was a statistically significant beta convergence in unemployment rates in the period before the crisis. This is consistent with both the sigma convergence in unemployment rates and the previous results concerning beta convergence of GDP per capita. Nevertheless, it can be observed that in the EU-15 there was a significant convergence in unemployment rates, thus the euro adoption did not play a particular role. On the other hand, in the crisis period (2007-2013) there was no significant convergence, neither in the eurozone nor in the EU.

Table 2: Absolute Beta Convergence in Unemployment Rate (1999-2007 and 2008-2013)

\begin{tabular}{|c|c|c|c|c|}
\hline \multirow[b]{2}{*}{ Period } & \multicolumn{2}{|c|}{ Eurozone 18} & \multirow{2}{*}{$\frac{\text { EU 15 }}{1999-2007}$} & \multirow{2}{*}{ EU 27 } \\
\hline & $1999-2007$ & $2008-2013$ & & \\
\hline No. obs. & 18 & 18 & 15 & 27 \\
\hline Beta coefficient & $-0.076^{* * *}$ & -0.044 & $-0.066^{* * *}$ & -0.049 \\
\hline Adj. R2 & 0.605 & -0.030 & 0.573 & 0.003 \\
\hline
\end{tabular}

Significance levels: 1 percent ${ }^{* * *}, 5$ percent ${ }^{* *}, 10$ percent ${ }^{*}$; constant not reported

Finally, by considering the long-term unemployment rate, we get the results in Table 3. Long-term unemployment (concerning people unemployed for at least 12 months) raises particular concern because it denotes persistence. Similarly to previous results, there was convergence in the pre-crisis period, both in the eurozone and in the EU, convergence that disappeared after the crisis for EU-27 and became less significant for eurozone.

Table 3: Absolute Beta Convergence in Long Term Unemployment Rate (1999-2007 and 2008-2013)

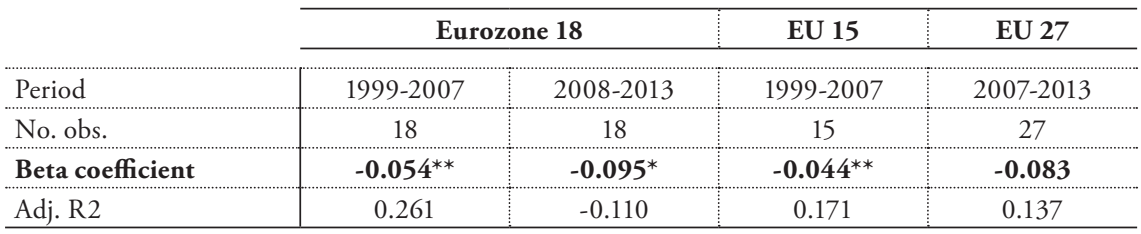

Significance levels: 1 percent ${ }^{* * *}, 5$ percent ${ }^{* *}, 10$ percent ${ }^{*}$; constant not reported 
A preliminary conclusion is that the euro adoption might have sustained the integration process, favoring the convergence of real variables - GDP per capita and unemployment rates - up to the crisis; however, such convergence can also be observed in the EU countries not belonging to the eurozone (this is especially true for unemployment and long-term unemployment rates). In the crisis period the previous convergence trends generally disappeared. Consequently, as for the eurozone, the overall evidence and results on "sigma and beta convergence" show a partially good performance in "normal times" (i.e., in the decade preceding the crisis $)^{35}$, while deterioration occurred during the "crisis years", highlighting the difficulty of the eurozone structure and governance to adequately react at and respond to severe aggregate shocks.

\subsection{The Impact of the Crises on Unemployment and Other Macroeconomic Variables}

Let us now address the discussion concerning the impact of the recent crises in the EU, with particular reference to the eurozone countries. First of all, a high differentiation across countries clearly emerges for all macroeconomic variables, also within the eurozone (see Tables A1-A6). In general, contrary to the US and Japan, in the eurozone:

(i) the GDP is far from the pre-crisis level, with steep declines in the peripheral countries, and a second recession can be observed in many other countries;

(ii) the unemployment rates have significantly risen and they are still growing in some countries, with expectations of persistence at high levels;

(iii) the deficit/GDP ratios are generally declining due to "austerity" policies, but the debt/GDP ratios are still growing due to the prevalence of the

35 We could also add that also in "normal times" some convergence was achieved across countries mainly due to the catching-up of the NMS. However there is some evidence that, while inequalities across EU countries diminished, "within-countries" disparities increased (Martin, 2009); similar results were obtained by Marelli (2007), by making use of both conditional and unconditional beta-convergence. 
contractionary real effects on GDP with respect to the fiscal consolidation effects.

If we focus now on the unemployment rate, we can see (Table 4) that in 2010, after the Great Recession, it reached similar values in the United States and in the eurozone - around 10 percent - but then in the former country it halved to a little more than 5 percent in 2015, while in the eurozone it reached a top value of 12 percent in 2013 and it is still above 11 percent. In Europe, only Germany exhibits an unemployment rate similar (even lower) to the one in the US (it is also rather low in the UK). The highest rates can be found in Greece (27.5 percent in 2013) and Spain (26.1 percent in the same year).

Table 4: Unemployment Rate (Unemployed as \% of Labor Force) - Selected Countries

\begin{tabular}{|c|c|c|c|c|c|c|c|c|c|c|}
\hline & 2007 & 2008 & 2009 & 2010 & 2011 & 2012 & 2013 & $2014^{*}$ & $2015^{*}$ & $2016^{*}$ \\
\hline Cyprus & 3.9 & 3.7 & 5.4 & 6.3 & 7.9 & 11.9 & 15.9 & 16.2 & 15.8 & 14.8 \\
\hline France & 8.0 & 7.4 & 9.1 & 9.3 & 9.2 & 9.8 & 10.3 & 10.3 & 10.4 & 10.2 \\
\hline Germany & 8.5 & 8.5 & 7.8 & 7.1 & 5.8 & 5.4 & 5.2 & 5.0 & 4.9 & 4.8 \\
\hline Greece & 8.4 & 7.8 & 9.6 & 12.7 & 17.9 & 24.5 & 27.5 & 26.6 & 25.0 & 22.0 \\
\hline Ireland & 4.7 & 6.4 & 12.0 & 13.9 & 14.7 & 14.7 & 13.1 & 11.1 & 9.6 & 8.8 \\
\hline Italy & 6.1 & 6.7 & 7.8 & 8.4 & 8.4 & 10.7 & 12.2 & 12.8 & 12.8 & 12.6 \\
\hline Portugal & 8.9 & 8.5 & 10.6 & 12.0 & 12.9 & 15.8 & 16.4 & 14.2 & 13.4 & 12.6 \\
\hline Spain & 8.2 & 11.3 & 17.9 & 19.9 & 21.4 & 24.8 & 26.1 & 24.3 & 22.5 & 20.7 \\
\hline Euro area & 7.5 & 7.5 & 9.6 & 10.2 & 10.1 & 11.3 & 12.0 & 11.6 & 11.2 & 10.6 \\
\hline UK & 5.3 & 5.6 & 7.6 & 7.8 & 8.0 & 7.9 & 7.6 & 6.3 & 5.6 & 5.4 \\
\hline $\mathrm{EU}$ & 7.2 & 7.0 & 8.9 & 9.6 & 9.6 & 10.4 & 10.8 & 10.2 & 9.8 & 9.3 \\
\hline United States & 4.6 & 5.8 & 9.3 & 9.6 & 8.9 & 8.1 & 7.4 & 6.2 & 5.4 & 4.9 \\
\hline Japan & 3.9 & 4.0 & 5.1 & 5.1 & 4.6 & 4.3 & 4.0 & 3.7 & 3.7 & 3.6 \\
\hline
\end{tabular}

Source: European Commission (European Economic Forecast, winter 2015). * forecasts

Some additional indicators of the European labor markets refer to the long-term unemployment rate that in 2013 was 6 percent in the eurozone $e^{36}$, ranging from 18.5 percent (Greece) and 13 percent (Spain) to 2.4 percent (Germany) and less than 2 percent in several countries (Austria, Sweden, Finland, Denmark, 
Luxembourg). ${ }^{37}$ These data raise concern not only because they highlight the social distress, but also due to the corresponding risk of persistence of unemployment at high levels for many years (hysteresis effects).

Concerning youth unemployment (15-24 years), in 2013 the eurozone rate reached 24.1 percent. The highest values were found, once more, in Greece (58.3 percent) and Spain (55.5 percent), but extremely high values were recorded also in Croatia (50.0 percent) and Italy ( 40.0 percent). The lowest value was shown in Germany $^{38}$ (7.8 percent), followed by Austria (9.2 percent), the Netherlands (11 percent) and Denmark (13 percent). In general, the crisis impact has been deeper on the weakest sections of labor markets: young people ${ }^{39}$ (who are the first to become unemployed because of the less stable jobs, not to mention the growing difficulties for "first entrants" in a situation of low and decreasing labor demand), women ${ }^{40}$, older workers (who are often unable to find alternative jobs), with a widespread increase in vulnerable employment as well (see ILO, 2010).

A second consideration concerning the impact of the crisis on the eurozone as a whole is that the previous comments (the points i-iii above) are even more applicable to the countries directly affected by the sovereign debt crisis and consequent austerity measures, especially the Piigs. Other countries have shown considerably different trends. The best example is Germany: positive real growth in all years after 2009, decreasing unemployment rate, achievement of a balanced budget, a debt/GDP ratio slightly above the pre-crisis level. However, the deceleration in GDP growth since 2012 proves that such countries are also affected because of the indirect impacts of the extensive austerity measures undertaken elsewhere.

37 Also outside the EU, Norway, Island, Japan, and the US.

38 The performance on this account was much better than the one in the US (where the youth unemployment rate was 15.5 percent).

39 Young workers, who have weaker work contracts, lower qualifications and less experience than older workers, have borne the brunt of the "Great Recession" (Arpaia and Curci, 2010). Thus, young people, who are long deprived of a decent job, become alienated and society's most valuable asset, its human capital, is being wasted and even destroyed (Stiglitz, 2012). See also Bruno et al. (2014) and Bruno, Marelli and Signorelli (2014), Choudhry, Marelli and Signorelli (2012).

40 As for the impact of the crisis on female labor, see Signorelli, Choudhry and Marelli (2012). 
A third consideration is that in the recent period the peripheral countries have tried to enhance their competitiveness - in some cases with a factual improvement in current accounts - through an "internal devaluation" obtained through the cut in wages or at least a restraint in the wage dynamics (in 20142015 many eurozone countries exhibited deflation conditions). But in order to eliminate the competitiveness gap with Germany, at least one decade of pain and suffering would be required; unless unit labor costs are mainly reduced through productivity increases, which requires strong innovations and investments. ${ }^{41}$

Finally, most of the European countries - especially in the periphery - have suffered because of the fall in internal demand. Consumption has been reduced due to the wage restraint, high unemployment and also high fiscal pressure (consequent to fiscal consolidation measures), that have cut the disposable income. As to the investment expenditure, unlike the US where total investment has undergone only a deceleration, in the EU it has plummeted: -15 percent is the cumulated loss in the 2007-2013 period. Thus, in order to have a strong recovery we need also a demand-management strategy supporting consumption and investment: in the former case, to guarantee viable conditions of social sustainability; in the latter case, to derive positive effects also from the supplyside (on innovations, potential output and productivity dynamics). ${ }^{42}$

\section{The Debate on Austerity Policies}

As discussed earlier (Section 3), massive austerity policies have been conducted in most eurozone countries, in order to improve the "confidence" of the markets and to comply with the rules imposed by EU institutions. However, according to a non-orthodox but large opinion, fiscal consolidation programmes have so

41 Reductions in labor taxes would also be useful to cut unit labor costs. However, given the current European constraints (Fiscal Compact), they are possible - e.g., in the case of Italy - only under two conditions: (i) an effective fight against tax evasion, (ii) a spending review that eliminates the waste of resources (together with inefficiencies of various kinds and episodes of corruption) and the perverse approach of linear cuts that reduce fundamental public services (even more important in this crisis period).

42 See also Marelli (2014). 
far been self-defeating. To explain this point ${ }^{43}$, let us introduce the debate on the fiscal multipliers that is closely linked to the dispute on the efficacy of austerity measures. In fact, we can contrast two key positions:

a) the supporters of tough austerity measures, in order to consolidate public finances, argue that fiscal multipliers are rather low and consequently restrictive fiscal policies do not cause large falls in income and production. For example, by underestimating the fiscal multipliers, EU policy-makers thought it would be possible to rapidly and safely re-balance public finances through quick and violent austerity measures (see Timbeau, 2012);

b) the opponents argue that drastic austerity policies are likely to be "selfdefeating", in the sense that the resulting loss of output is so large that the debt/GDP ratio increases. Even the IMF (2012) now maintains that the value of the fiscal multipliers, since the Great Recession, has significantly increased, suggesting a more gradual fiscal adjustment.

To better explain the two positions, we recall that, according to the traditional Keynesian view, a cut in public expenditure or an increase in taxation leads to a more or less significant fall in production and income, perhaps with some lags. The subsequent Monetarist and New Classical Macroeconomic schools challenged this consolidated view, emphasizing the existence of potential "nonKeynesian" effects. In addition to a possible crowding-in of private investment, following the reduction in public expenditure, the expectation of a long-run balanced budget consequent to the fiscal adjustment brings about an increase in current consumption (this is the "Ricardian equivalence" proposition). Moreover, higher credibility of economic policies and better sustainability of public debt allow a reduction in interest rates (this is the "confidence factor"), thus encouraging private investment. Pro-market economists have for a long time emphasized these non-Keynesian effects. By assuming a reduced size of the 
fiscal multipliers, severe fiscal contractions can be "expansionary". ${ }^{44}$ However, different caveats are appropriate.

A first element to take into consideration is the time horizon. In fact, the most sensible analyzes distinguish between a short-run impact of fiscal consolidation which is mostly negative - and the long-run effects, that could turn to be positive (i.e., non-Keynesian). The majority of models imply that a cut in expenditure, for example, lowers demand in the short run, but then subsequently the economy recovers to its previous level (Gros, 2012).

The second element is the specific instrument of the fiscal policy that is manoeuvred: adjustments realized through spending cuts are less recessionary than those achieved through tax increases. ${ }^{45}$ This is the position of Alesina and Giavazzi (2012), who maintain that EU economies will remain stagnant or fall into recession (and debt ratios will not decrease) if adjustments are mostly made on the tax side. However, it is also possible to rejoin that the opposite proposition that tax cuts would reduce budget deficits, because faster economic growth will generate higher revenues, has been tested several times and confuted, since tax cuts were invariably followed by higher deficits (Gros, 2012).

A second argument by Alesina and Giavazzi (2012), who in the more recent contributions have admitted certain excesses in the thesis of expansionary austerity, is that spending-based consolidations should be accompanied by the "right" polices, including easy monetary policy, liberalisation of goods and labor markets, and other structural reforms; in this case, consolidations tend to be less recessionary or even have a positive impact on growth. However, we can reply to this point that: (i) supply-side reforms are useful to enhance economic growth in a long-run perspective, but their impact is deferred; (ii) in the current eurozone situation low or negative growth depends mainly on the lack of aggregate 44 See the seminal paper by Giavazzi and Pagano (1990), the empirical research by Alesina and Perotti (1997) and the recent analysis by Perotti (2012).

45 As to the composition of tax and expenditure reforms, a shift towards the VAT and away from income taxes seems preferable; on the expenditure side, it is suggested to raise the retirement age (for pension allowances) and to cut government employment. Furthermore, only spending-based adjustments eventually lead to a permanent consolidation of the budget (Alesina and Giavazzi, 2012). 
demand (as shown in Section 4); (iii) spending cuts or "reviews" are in some cases useful or even necessary (e.g., when they attack inefficiencies, wasted resources and corruption), but in other instances they are rather difficult to implement or may be counter-productive. The latter is the case of investment expenditure; on the other hand, social expenditure cannot be cut easily, given the characteristics of the Welfare State in Europe (although it has already been slashed in many countries). ${ }^{46}$

Contrary to Alesina and Giavazzi's results, Heyer (2012) maintains that the multipliers associated with public expenditure are much higher than those observed for taxes: for the eurozone, for instance, the multiplier in one year is 2.6 if government spending is used as an instrument of fiscal consolidation and 0.4 if the instrument is taxation. Similar results are obtained by EC (2012): in particular, first-year multipliers are larger if the fiscal consolidation is based on government expenditures (government investment in particular) ${ }^{47}$; moreover, fiscal multipliers are nonlinear and increase in crisis periods.

This is the third caveat about the size of fiscal multipliers that depend on the business cycle conditions. They are higher in crisis periods due to uncertainty about aggregate demand and credit conditions, presence of slack in the economy, larger share of consumers that are liquidity constrained. In fact, the multipliers are larger in a crisis period (by a factor of about one half) and even larger in a crisis period in which many trade partners consolidate (in the latter case they should be roughly multiplied by a factor of 5/3). Also Auerbach and Gorodnichenko (2012) corroborate the traditional Keynesian idea that the multipliers are higher in recessions than in periods of expansion: the impact of a shock on public expenditure would be between 0 and 0.5 in expansions, and between 1 and 1.5 in recessions.

46 On the revenue side, an alternative to tax increases is the privatization of public firms or the dismissal of public assets (but in this case there is a problem of the right timing).

47 Most of the empirical estimates of the first-year spending multipliers - in normal times - are located in the range of 0.4 to 1.2; at the same time, the values are lower (often below 0.7 ) for tax multipliers. 
Turning back to the general debate on the size of the multipliers, recent empirical studies reveal that the multipliers differ by huge amounts, even by signs. The IMF (2012) maintains that the value of the fiscal multipliers, since the Great Recession, is significantly higher than the ones previously estimated. In the past (during the three decades ending in 2009), the average value of fiscal multipliers for advanced economies was assumed to be close to 0.5 ; the new IMF estimates place it in the range from 0.9 to 1.7 .

In other econometric estimations the size has been found even greater. For example, several economists from leading institutions ${ }^{48}$ compared their assessments based on eight different macroeconometric models (mainly DSGE models) for the US and four models for the eurozone; they found that the size of many multipliers is large, particularly for public expenditure and targeted transfers (see Auerbach and Gorodnichenko, 2012). The OFCE (Observatoire français des conjonctures économiques) estimates a multiplier for the eurozone as a whole in 2012 equal to 1.6, comparable to the assessments for the US and UK (Timbeau, 2012). Also Christiano, Eichenbaum, and Rebelo (2011) agree that the government spending multiplier may be very large, especially when the nominal interest rate is zero (this result is also obtained through a dynamic, stochastic, general equilibrium model).

The National Institute Global Econometric Model has made an attempt to estimate the quantitative impact of coordinated fiscal consolidation across the EU. The main conclusion is that while in normal times fiscal consolidation would lead to a fall in debt/GDP ratios, in current circumstances it has a much worse impact on economic growth and has led to higher debt ratios in 2013 in the EU as a whole (rather than lower): in fact, "coordinated austerity in a depression is indeed self-defeating" (Portes, 2012). The main reasons are the following: (i) the simultaneous fiscal consolidation in many countries depresses also the external demand, especially in the EU where the spillover effects are large; (ii) the fiscal tightening does not help in reducing interest rates, since they were already 48 IMF, OECD, European Commission (EC), European Central Bank (ECB), US Federal Reserve (FED), Bank of Canada. 
extremely low (i.e., the "zero lower bound"); (iii) households and firms are liquidity constrained (a recurrent situation when there is high unemployment) and cannot benefit from improved expectations on public accounts.

"Indeed, austerity economics has not worked in one single case in Europe in the last two years." (Madrick, 2012). Also Corsetti (2012) has the same opinion: austerity has gone too far. Even a liberal economist like Zingales (2012) admits that the immediate impact of cuts in public expenditures is an increase in unemployment that in turn causes a reduction of aggregate demand and GDP: thus the economies of Southern Europe risk to die not only because of the high spread, but also because of an excessive cure, i.e., the austerity.

Wyplosz (2012a) recalls that fiscal discipline is good in the long run (from this point of view the Fiscal Compact can be accepted), but "adopting contractionary fiscal policies in the teeth of a double-dip recession never made sense". The situation is complicated since financial markets want to see both commitment to fiscal discipline and immediate growth; but how can confidence be restored as the crisis economies plunge into recession? ${ }^{49}$ Moreover, even if we agree that in some countries structural reforms are necessary to reinforce growth, their effects are too slow for rapid relief. A gradual and smooth fiscal consolidation is preferable to a strategy of reducing public imbalances too rapidly and abruptly (Heyer, 2012).

49 Stiglitz (2012) emphasizes that "markets on their own are not stable" and refers to an "automatic destabilizer" that is embraced in Europe, since "States with balanced-budget frameworks are forced to cut spending as tax revenues fall". Gros (2012) maintains that some market participants might not be rational, demanding a higher risk premium following a short-term deterioration of the debt ratio, although conscious of the longer-term positive impact of deficit cutting on the debt level. Thus, the key question is whether financial markets focus on the short run or on the long run. 


\section{Concluding Remarks: The Need for Innovative Policies in the Eurozone}

The current situation of stagnation and deflation in the eurozone ${ }^{50}$, accompanied by high and persistent unemployment, requires some changes at different levels. We divide this final section into three sub-sections: (i) reforms in the governance of the EMU and hopeful changes in its architecture; (ii) proposed changes in the current macroeconomic policies; (iii) innovative policies to fight unemployment (in particular youth unemployment).

\subsection{Reforms in the Governance of the EMU}

A recognized critical shortcoming of the EMU construction and governance is the complete asymmetry between the two key macroeconomic policies. While monetary policy has been centralized, fiscal policy is still assigned to national governments. It is true that the GSP tried to establish some constraints on national public budgets, but (in addition to the ascertained failures of the Pact) this is not enough. Standard OCA theories (see Section 2) maintain that a working monetary union requires not only convergence of economic and institutional structures (to avoid asymmetric shocks), accompanied by an adequate degree of market flexibility and labor mobility, but also fiscal transfers stemming from a centralized budget.

Thus, the lack of a federal budget that could carry out counter-cyclical policies $^{51}$ is a critical weakness. A second shortcoming is the absence of effective mechanisms favoring long-run convergence among the economies, despite the old "Lisbon Agenda" and the current "Europe 2020" plan. It is difficult to maintain

50 The QE introduced by the ECB in early 2015 - together with the depreciation of the euro and the fall in the oil price - has partially improved the growth prospects, although in many countries the foreseen rate of growth remains too sluggish to reduce unemployment in a significant way.

51 Zingales (2012) himself advocates a centralized system, at the EU level, of transfers, not only for supporting banks but also for helping unemployed people. He proposes an unemployment benefit system equal for all countries, to be financed by EU funds and managed at the EU level. This is also seen as an important message to public opinion: Europe is sympathetic not only toward banks, but also to private citizens. 
a common currency in a group of countries characterized by huge differences in competitiveness and current account balances. ${ }^{52}$ From this point of view, the peripheral countries exhibit several similarities between them, considering the low degree of competitiveness and the deficits in the current accounts of the balance of payment, in contrast with the surpluses of Germany and other core countries (see Section 2). The situation has partially improved in the recent period only thanks to a painful "internal devaluation" (Section 4).

Is the euro break up a likely scenario? At the moment it is still implausible, since disintegration will bear too heavy costs. ${ }^{53}$ However, survival of the euro will depend on the capacity to find a solution for the mentioned problems of real convergence. This requires a stronger involvement of the EU in the implementation of structural funds, investment and infrastructure networks, policies for R\&D and human capital, etc.: i.e., providing adequate financial substance to the "Europe 2020" or similar plans. This financial need adds to the necessity of a centralized budget for stabilization purposes, as argued before. For both needs, EU budget should be progressively increased over time. ${ }^{54}$ On the contrary, with a budget amounting to a mere 1 per cent of EU's GDP - compared with about 40 or 50 percent of national budgets - one wonders whether a monetary union could be preserved. In future, not only would a bigger budget be necessary, but considering the significant different degree of integration of eurozone countries, a separate budget for the euro area appears appropriate.

A real and progressive integration process would require not only adequate financial resources but also consistent institutional reforms (see Sapir and Wolff,

52 The new "macroeconomic imbalances" procedure within the reformed GSP is not the right solution: such imbalances cannot be eliminated only by means of new compelling rules and the threat of fines. On the importance of macroeconomic imbalances within such procedure see also Gros and Giovannini (2014).

53 In our opinion, the exit from the eurozone of individual countries will also induce excessive costs, much higher than the potential benefits: rising interest rates and capital outflows, worse public debt sustainability and much higher risk of default, rising inflation (that will shortly reduce the possible benefits of the initial devaluation). This is why even the new Greek government, appointed after the 2015 elections, that is so critical of the "troika" and the EU institutions, does not seem willing to leave the eurozone.

54 The decision of the EU Council (February 2013) to set a ceiling for the 2014-2020 budget is quite astonishing, implying a cut in real terms - it is the first cut in more than fifty years (i.e., since the Community exists) - by about 3 percent. The decision was instigated by the tough position of the United Kingdom, soon followed by Germany and some other countries. 
2015 among others). Yet also on this ground the perspectives are not clear. As we know, the recent financial and sovereign debt crisis has spurred many projects for institutional innovation, also by the EU bodies. For example, in June 2012 the EU President van Rompuy presented (together with the President of the EU Commission, of the Eurogroup and of the ECB) a document (Toward a genuine economic and monetary union), foreseeing a stronger integration, leading to: (i) a bank union, (ii) a budget union, (iii) an economic union, and (iv) (at the end) a political union. The document has been followed by more detailed proposals by the EU Commission. However, a limited progress has been achieved only on point (i) after many compromises ${ }^{55}$; it is hard to predict when the remaining steps could be attained.

On the financial side, survival of the euro will also necessitate effective crisis management instruments, that could be more helpful in comparison to the ones introduced in a confused and improvised way (see Section 3). ${ }^{56}$ The principle should be that an authentic solidarity among the eurozone countries goes hand in hand with stronger supra-national controls on all members (to face the "moral hazard" dilemma); however, the debate on the usefulness of Eurobonds $s^{57}$ is still going on, so far with a strong opposition from Germany.

Finally, we can argue that in a globalized world where the competitive pressure coming from the new economic powers - in America, Asia and other world regions - is every year more intense and where a fragmented Europe would be certainly fading, we need open-minded and far-sighted policy-makers, both in national Governments and in the EU institutions, in order to preserve the aims and spirit of a momentous process of integration involving several generations.

55 The bank union began in November 2014 but the ECB's supervision is limited to the biggest banks and financial institutions.

56 As to the new ESM fund, a sum of 100 billion euro has been committed to support Spanish banks (40 billion have been actually used). A much lower amount (less than 10 billion) has been used to help Cyprus.

57 Eurobonds are backed by several economists and policy-makers (even the EU Commission presented a proposal with different types of Eurobonds); see also Schäfer (2012). 


\subsection{Proposed Changes in the Macroeconomic Policies}

If an ideal scenario of a fully integrated European economy ${ }^{58}$ is unrealistic for the coming years, what should be done at least to overcome the current "growth crisis"? A first consideration is - to repeat - that austerity measures have been too harsh, especially in countries needing fiscal consolidation, also because of an erroneous estimation of the fiscal multipliers (see Section 5), leading to the devastating effects on production, employment and growth. In this context, even the IMF already in 2012 (IMF, 2012) advocated not only the maintenance of a very accommodating monetary stance, including unconventional measures, but also a smoothing of the fiscal adjustments..$^{59}$ As Romano Prodi, former President of the EU Commission, once said (talking about the GSP) - fiscal rules are useful unless when they become just "stupid".

EMU survival desperately requires the EU policies to be rapidly and strongly re-oriented towards the objective of economic growth. EU policy-makers should realize that fiscal discipline - such as that required by the Fiscal Compact or the stricter rules inflicted to countries demanding financial assistance - should be assessed in a medium-term horizon and should be accompanied by an adequate "growth policy" at the EU level or at least by fiscal coordination.

Clearly the double-dip recession in the eurozone has been related not only to the restrictive policies and fiscal consolidation plans, but also to the wrong structure of macroeconomic adjustments in this area: tight austerity has been imposed on the debtor (southern) countries while the creditor (northern) countries continued to follow policies aimed at balancing the budget (see De Grauwe, 2012). As we have seen, the peripheral countries have also been forced to reduce wages and prices relative to the core countries, in order to obtain an "internal devaluation"

58 The final outcome of this scenario could be the set up an "EU Government", as imagined in the past by J. Delors and recently by many economists (like J. Stiglitz, J.P. Fitoussi and R. Solow). But, of course, there is the opposition of many countries to accept further steps in integration that might end up in a political union.

59 A certain moderation of the EU stance was perceived in early 2015, since some "flexibilities" were introduced, for countries respecting the GSP rule (the 3 percent ceiling in the debt/GDP ratio), in terms of the consideration of some public investments (e.g., corresponding to the use of EU structural funds); although this is not yet formally the adoption of a "golden rule", i.e., the exclusion of investments from the computation of deficits. 
(a surrogate for currency devaluation). An alternative solution would be to induce the countries with sound fiscal positions and that have room for fiscal manoeuvre - like Germany - to accept expansionary policies. ${ }^{60} \mathrm{~A}$ "coordinated domestic demand-led policy" would be particularly beneficial. ${ }^{61}$ As Wyplosz (2012b) claims: "Germany must also conclude that playing the locomotive is in its deep interest and that a little bit of inflation is much more preferable than letting the euro disappear".

This is even more true today, since deflation has been dominant in eurozone countries at the end of 2014 and the beginning of 2015. Also, the ECB must now act precisely on the basis of its mandate ( 2 percent target of inflation), even just considering its primary goal (price stability). As a matter of fact, in the recent period the ECB has adopted a battery of unconventional measures ${ }^{62}$ : after the OMT plan decided in 2012 (and likely never used), that was so important to reduce interest rates on sovereign debt (especially the spreads of peripheral countries), the new "targeted long-term refinancing operations" (TLTRO, launched in 2014) (33 $^{3}$ and the "quantitative easing" (initiated in 2015) should help in ending the credit crunch; but it is crucial to identify the most appropriate means to ensure that the liquidity given to the banks by the ECB really flows to production and to the real economy.

However, as President Draghi himself has recognized ${ }^{64}$, monetary policy is not enough to solve the current problems of feeble economic recovery in the eurozone. He has also finally accepted that - to reinforce economic growth -

60 Notice, for instance, that even in Germany public investments are a mere 1.5 percent of national GDP (one of the lowest incidences in the EU).

61 This is the conclusion of a recent investigation (Garbellini, Marelli and Wirkierman, 2014) that has quantified, within an input-output framework, the possible benefits deriving for the eurozone countries from such a coordinated policy. In the same paper, it has been found that during the Great Recession the "Piigs" have generally been more sensitive to domestic demand reductions while core-eurozone countries have been more vulnerable to (and inflicting more damage to) their trade partners.

62 However, despite many requests, it is almost impossible that ECB will change completely its strategy to become a "lender of last resort" also for Governments, i.e. providing money financing of public deficits.

63 At the same time the key interest rate has been further reduced to almost zero ( 0.05 percent).

64 Jackson Hole speech (ECB, August 2014). 
structural reforms continue to be important, but should be accompanied by the policies to sustain aggregate demand.

For instance, a spur of investment would enhance long-term growth, with positive spillovers to the rest of Europe (Stiglitz, 2012). An increase of public investment expenditure would allow an immediate relief for the economy: for example, investment in infrastructure, transport, communications (Digital Agenda), but also human capital, higher education and research. The investments of private enterprises that have plummeted in recent years should benefit from the reversal of expectations and confidence and from a more efficient performance of the credit mechanism. It is almost superfluous to point out that a revival of investment not only supports aggregate demand in the short term but allows an increase of long-run growth, especially if the utmost attention is given to the role played by innovation. ${ }^{65}$ Let us hope that at least the plan launched by Jean-Claude Juncker, the President of the new EU Commission, comprising a programme worth 310 billion euro of public and private investments, will be soon effective. ${ }^{66}$

\subsection{Policies Needed to Fight Youth Unemployment}

Recent macroeconomic trends, together with the inadequate or delayed policy responses - i.e., the "too little too late" approach (see section 6.2) - have led to a double-dip recession and to recent deflation in the eurozone. Apparently a long period of stagnation, or feeble recovery, with persistent unemployment without job creation lies ahead. In particular, cyclical unemployment is becoming structural and persistent in some countries, because of hysteresis factors.

65 Industrial policies as well as public investment should be directed to this end. Instead of an indiscriminate support to all firms in all sectors, it would be appropriate to target the aid toward firms that actually expand "good" jobs or to those that act as leaders in innovation processes, so that the benefits pour to the entire industrial and economic system. See Cappellin et al. (2014).

66 The critics refer in this case not only to the limited amount of financial resources available from the EU Commission and the European Investment Bank, EIB (21 billions of euro), but also to the long period ( 3 years after mid-2015) for the realization of the investment projects. An interesting proposal, by some Governments and also individual economists, is the possibility that the EIB bonds should be bought by the ECB, in order to widen the range of activity of EIB itself (for much bigger amounts compared to what ruled by the QE). 
Thus, the first policy response is that macroeconomic policies should become less restrictive and should be accompanied by growth-oriented policies on the supply side. However, at this point it is too late to solve the labor market problems just acting on aggregate demand. Structural policies and specific labor market policies and programmes are fundamental at this stage, to contrast persistence effects and structural unemployment.

This is even more important for young people, since they particularly suffer because of the bad long-run consequences of unemployment, such as loss of work experience and human capital, lower employability and reduced earnings over the entire life cycle ${ }^{67}$, poorer job quality and precarious employment (see Scarpetta, Sonnet and Manfredi, 2010; O'Higgins, 2012; Brada, Marelli and Signorelli, 2014). Thus, the expansion of a "lost generation" in many European countries highlights the need to adopt effective active and passive labor policies. ${ }^{68}$ Passive policies and social protection are necessary because the dramatic situation in labor markets is bringing about profound social and even political consequences. Generous active labor policies ${ }^{69}$ are badly needed, especially in the countries where a large proportion of young people (in some cases almost half) are not able to find a job.

In the EU, within the comprehensive package of EU policy initiatives called "Youth on the Move" (European Commission, 2010), the "Youth Opportunities Initiative" is designed to prevent early school leaving, help youngsters in developing skills relevant to the labor market, assisting young people in finding

67 Bell and Blanchflower (2011) found evidence that spells of youth unemployment have harmful impacts on a number of outcomes-happiness, job satisfaction, wages and health-even many years later.

68 As for the non linear relationship between active and passive labor policies in crisis time, see Dal Bianco, Bruno and Signorelli (2015). The general impact of institutions and policies on youth (and total) unemployment is reviewed in Marelli, Choudhry and Signorelli (2013).

69 ILO (2012), that explicitly considers also macroeconomic and growth policies, distinguishes between: (i) active labor market measures, including development of public employment services, wage and training subsidies or tax cuts (that can motivate employers to hire young people); (ii) programmes to offset the mismatch of technical skills among youth, such as vocational training programmes, re-training of unemployed or discouraged youth, workplace training schemes, the creation or improvement of apprenticeship systems, entrepreneurship training programmes, soft and life skills training programmes for disadvantaged youth. 
a first good job and ensuring on-the-job training. ${ }^{70}$ In particular, the "Youth Guarantee" Recommendation (launched in 2013) requires that Member States should put in place measures to ensure that young people (up to age 25) receive a good quality offer of employment, continued education, an apprenticeship or a traineeship within four months of leaving school or becoming unemployed. However, this approach has so far not been very successful, considering the heterogeneous experiences encountered in different countries and also within countries (the initial implementation refers to 2014). Moreover, education systems should be reformed and innovative school-to-work transition systems should be introduced. ${ }^{71}$

Therefore, a combination of active and passive policies, at the national and community level (with a much bigger EU budget allocated to this end) ${ }^{72}$, accompanied by proper macroeconomic policies, is the only way to tackle the (youth) European unemployment problem.

70 The specific actions financed directly by the EU include: youth guarantee schemes, apprenticeship and traineeship programmes, support schemes for young business starters and social entrepreneurs, volunteering opportunities, continuous support for Erasmus and Leonardo da Vinci programs (see Eurofund, 2012).

71 See Quintini and Manfredi (2009), Pastore (2015). As for education, many studies suggest that a "dual educational system", characterised by a key role of apprenticeship (young people are provided training while at school and not after school) and widely diffused in Germany, is probably the most effective way for ensuring a smooth transition from schools and universities to the labor market.

72 A greater role for the EU institutions can be foreseen in the implementation of the plans, in order to guarantee the efficiency conditions in the use of the EU funds and the overall effectiveness of the program. 


\section{Appendix}

Figure A1: GDP Per Capita Dispersion

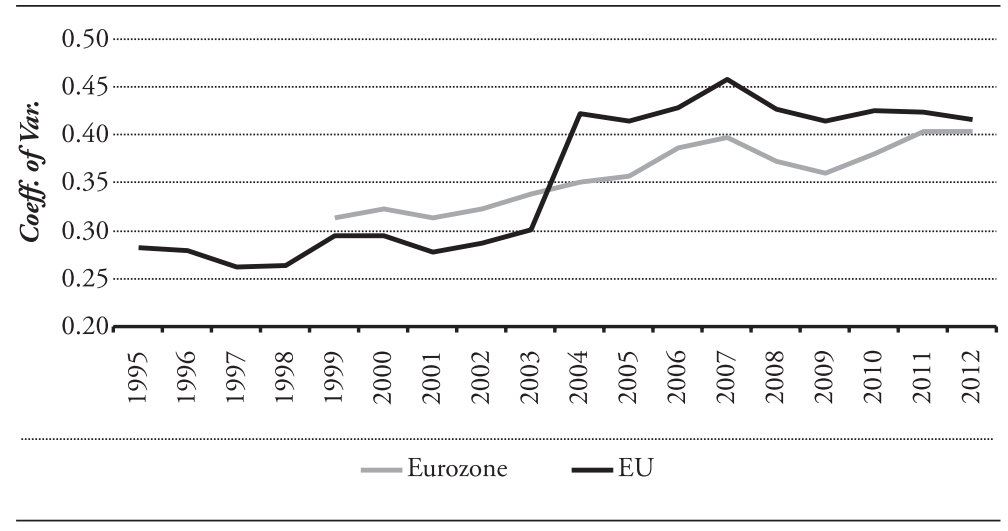

Figure A2: Unemployment Rate Dispersion

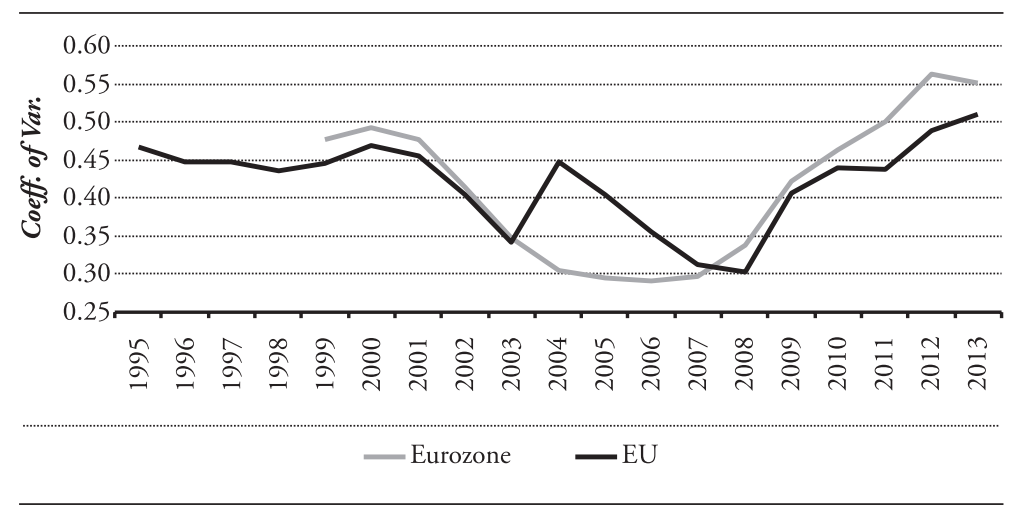


Figure A3: Long-Term Uemployment Rate Dispersion

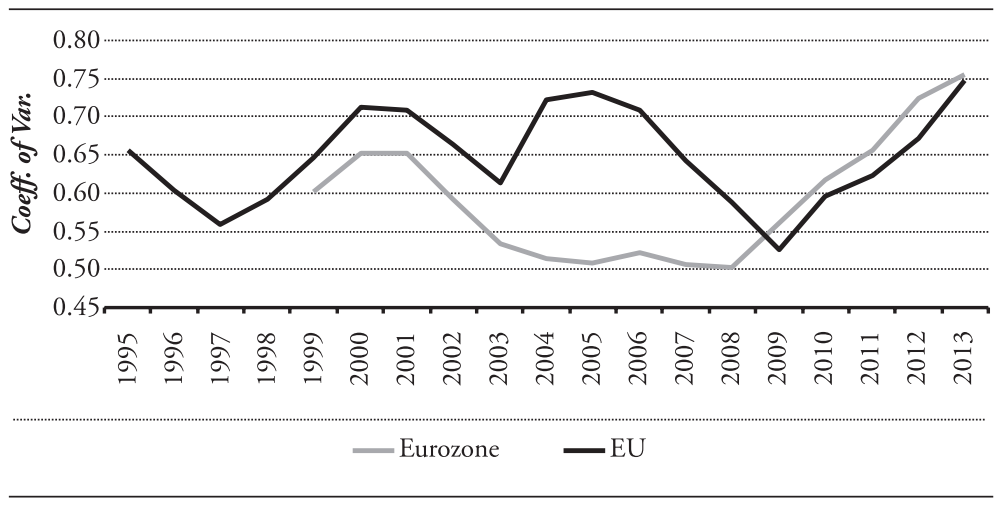

Figure A4: Debt/GDP Ratio Dispersion

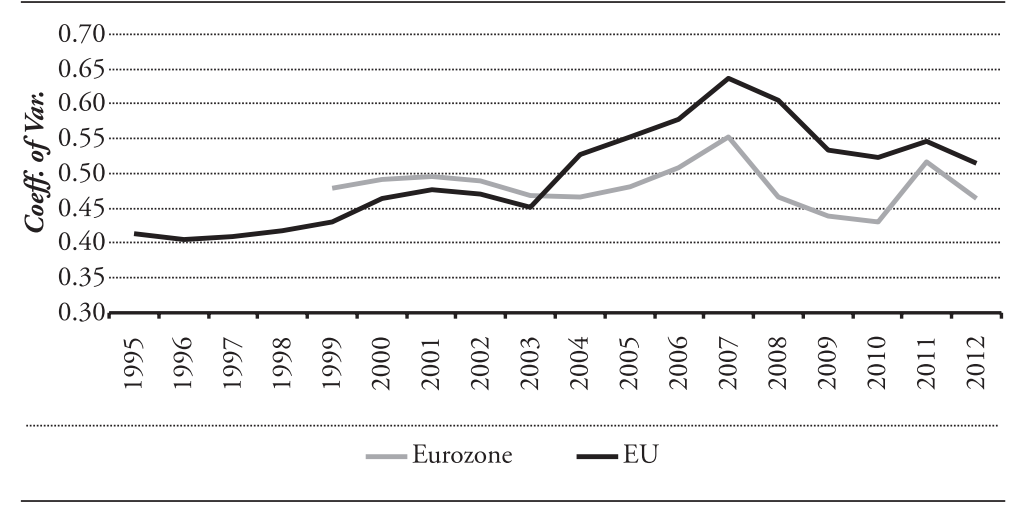


Figure A5: Deficit/GDP Ratio Dispersion

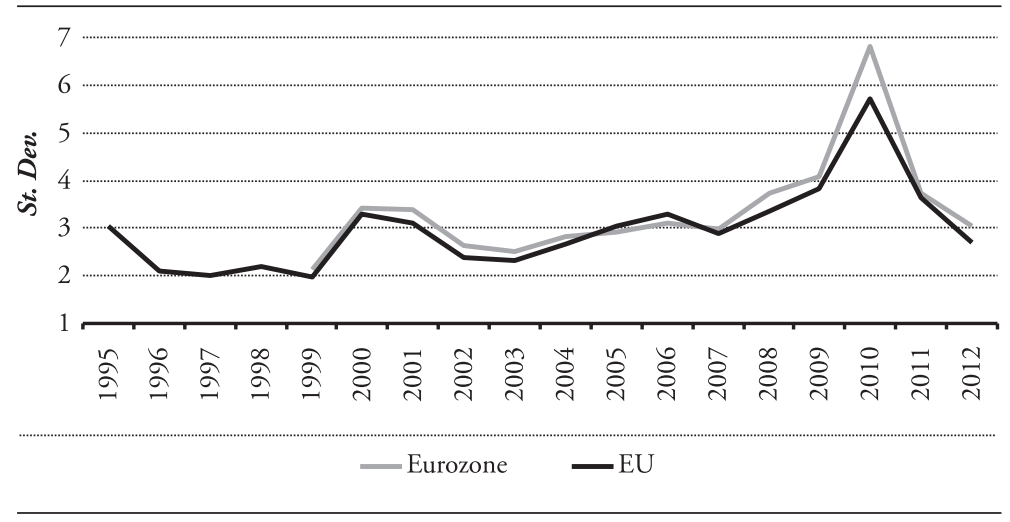

Figure A6: Primary Balance/GDP Ratio Dispersion

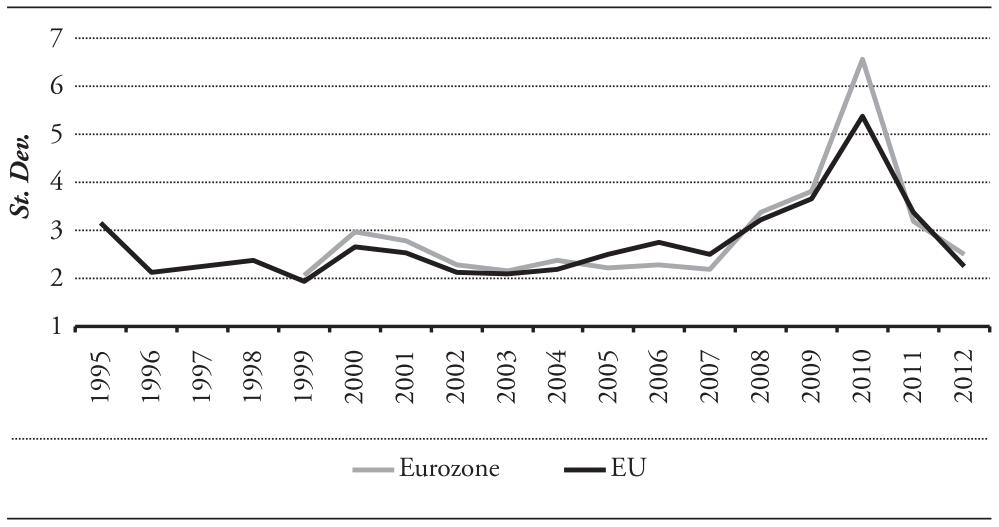




\section{Figure A7: Interest/GDP Ratio Dispersion}

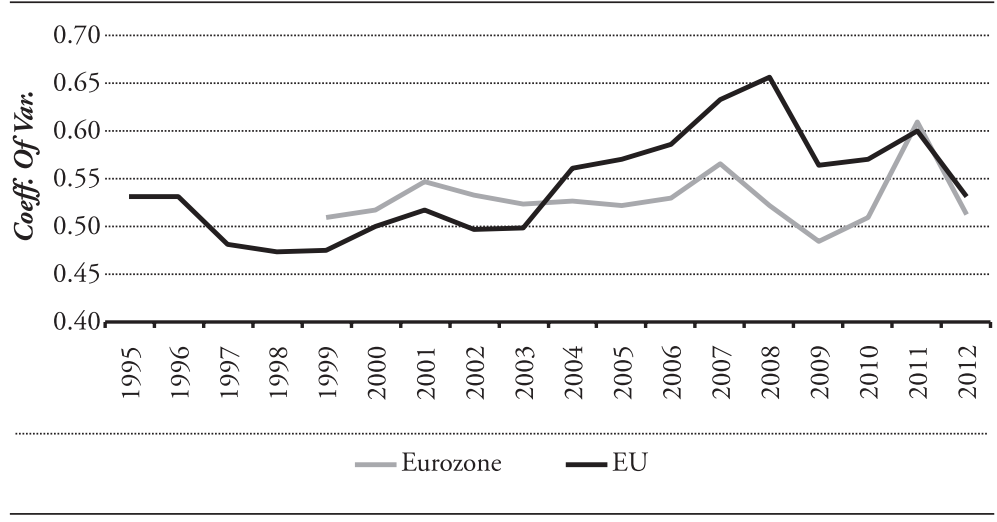




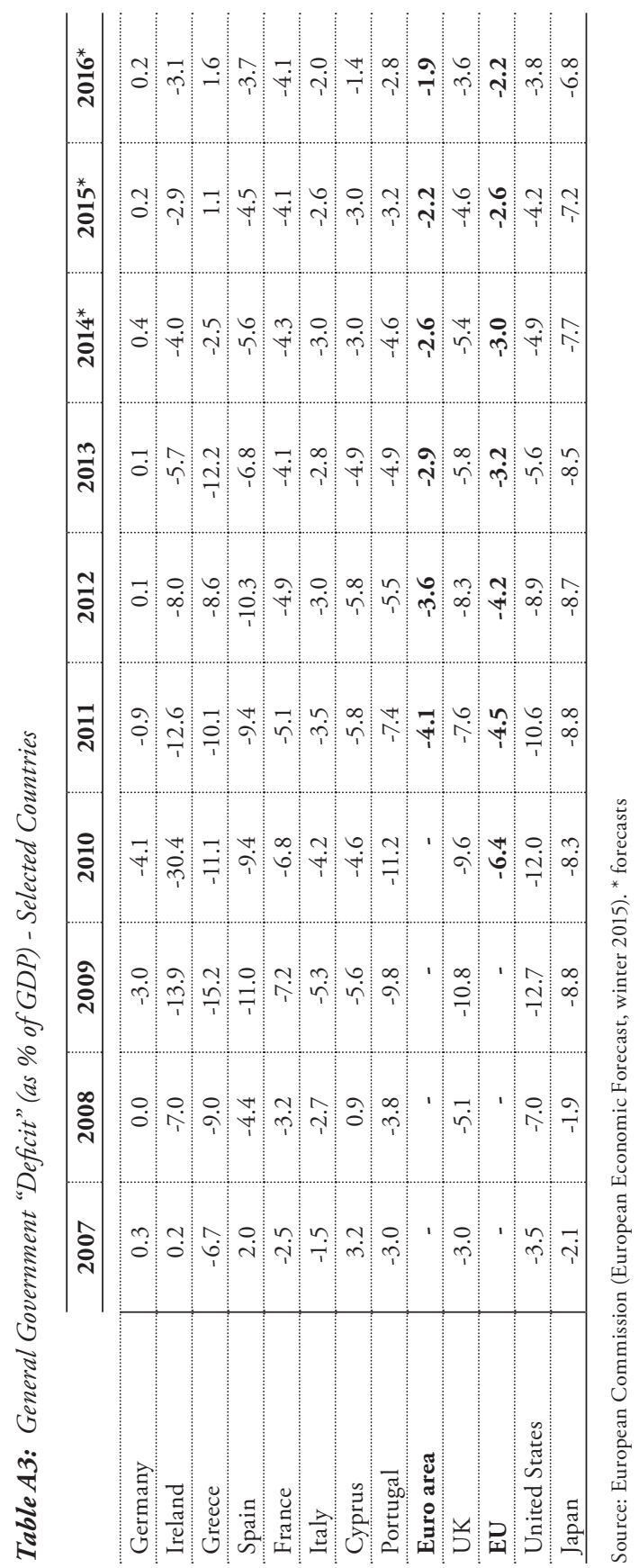




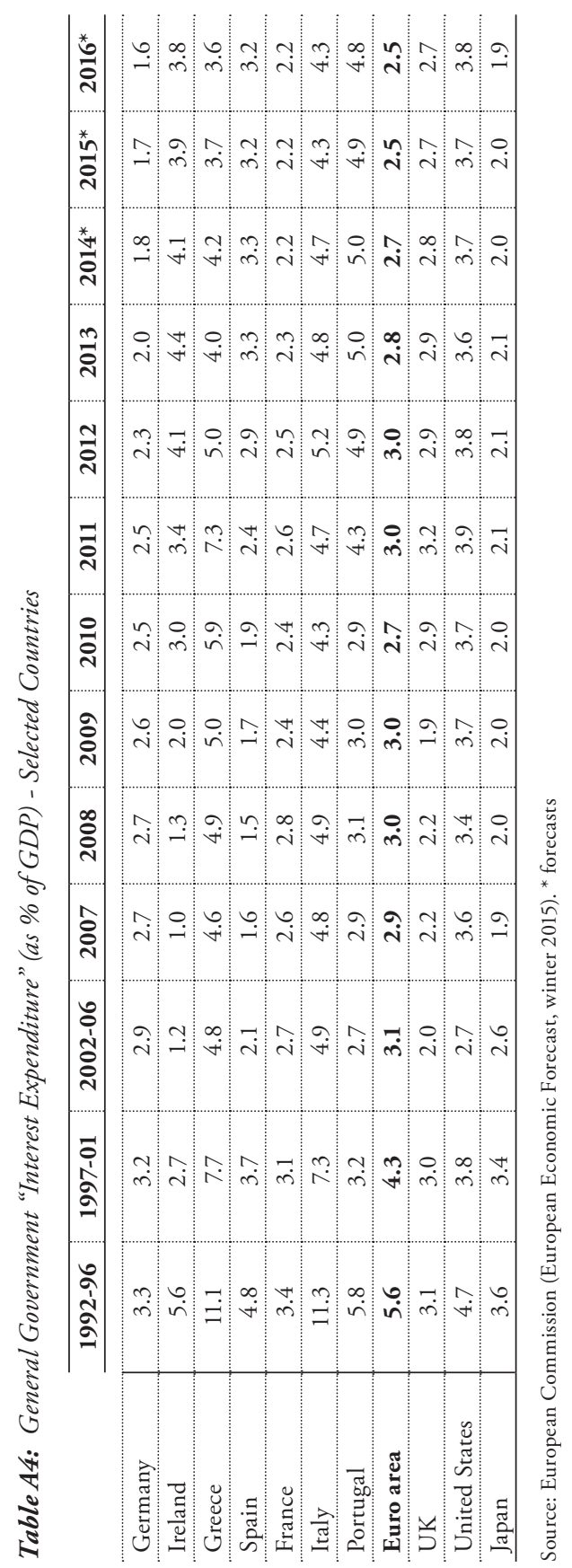




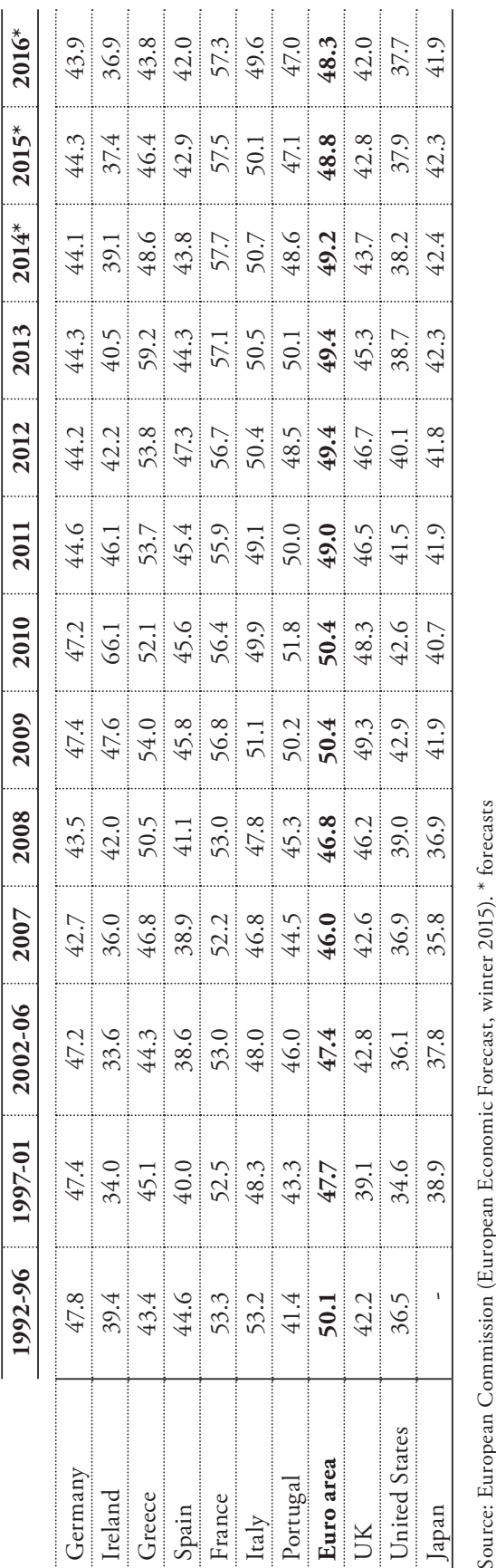




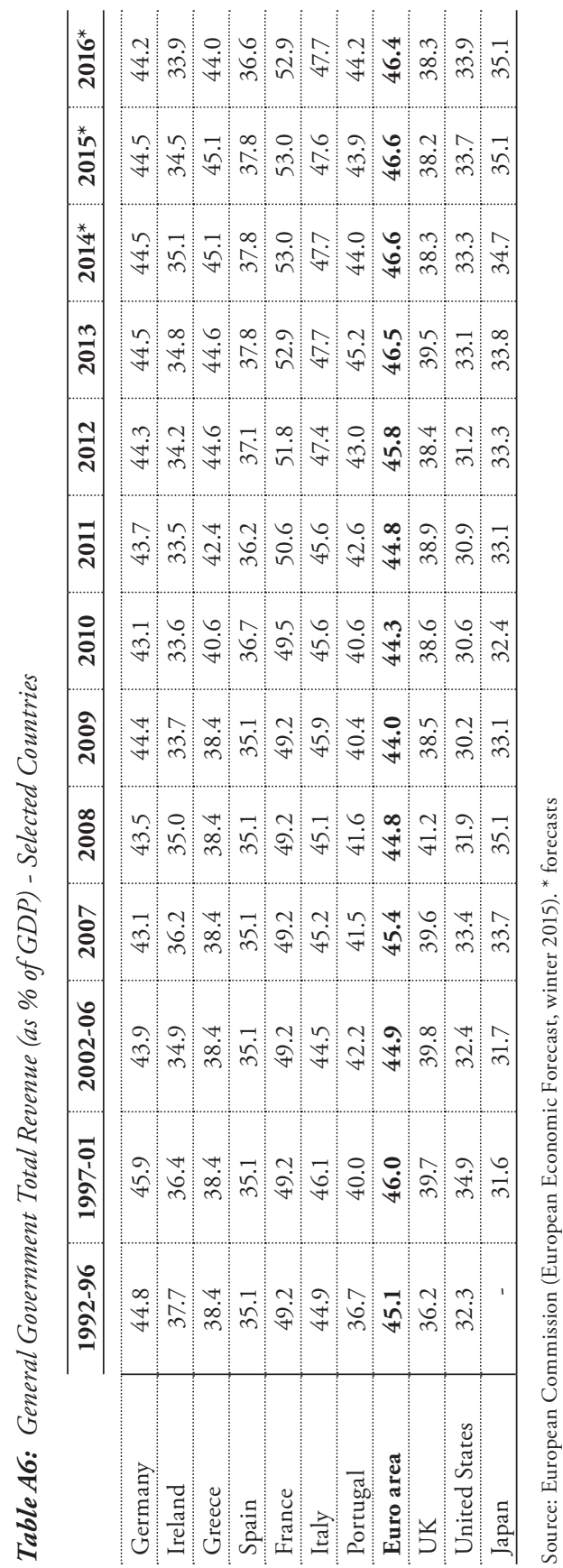




\section{Literature}

Alesina, Alberto, Silvia Ardagna and Vincenzo Galasso, 2011, "The Euro and Structural Reforms", Review of Economics and Institutions, 2(1), pp. 1-37.

Alesina, Alberto and Francesco Giavazzi, 2012, "The austerity question: 'How' is as important as "how much"', VoxEU.org, April 3, 2012, http://www.voxeu. org/article/austerity-question-how-important-how-much (accessed November 26, 2015).

Alesina, Alberto and Roberto Perotti, 1997, "Fiscal Adjustments in OECD Countries: Composition and Macroeconomic Effects", International Monetary Fund Staff Papers, 44(2), pp. 210-48. http://dx.doi.org/10.2307/3867543

Arpaia, Alfonso and Nicola Curci, 2010, "EU Labour Market Behaviour During the Great Recession”, European Economy, No. 405, pp. 1-51, Brussels: European Commission.

Auerbach, Alan J. and Yuriy Gorodnichenko, 2012, "Measuring the Output Responses to Fiscal Policy", American Economic Journal: Economic Policy, 4(2), pp. 1-27. http://dx.doi.org/10.1257/pol.4.2.1

Barro, Robert J. and Xavier Sala-i-Martin, 1995, Economic growth, New York, NY: McGraw-Hill.

Bell, David N.F. and David G. Blanchflower, 2011, "Young People and the Great Recession”, Oxford Review of Economic Policy, 27(2), pp. 241-267. http://dx.doi. org/10.1093/oxrep/grr011

Brada, Josef C., Enrico Marelli and Marcello Signorelli, 2014, "Young people and the labor market: key determinants and new evidences", Comparative Economic Studies, 56(4), pp. 556-566. http://dx.doi.org/10.1057/ces.2014.30 
Bruno, Giovanni S.F., Misbah Tanveer Choudhry, Enrico Marelli and Marcello Signorelli, 2014, "Youth Unemployment: Key Determinants and the Impact of Crises", in Miguel A. Malo and Dario Sciulli, eds., Disadvantaged Workers: Empirical Evidence and Labour Policies, pp. 121-148, Heidelberg: Springer. http:// dx.doi.org/10.1007/978-3-319-04376-0_7

Bruno, Giovanni S.F., Enrico Marelli and Marcello Signorelli, 2014, "The Rise of NEET and Youth Unemployment in EU Regions after the Crisis", Comparative Economic Studies, 56(4), pp. 592-615. http://dx.doi.org/10.1057/ces.2014.27

Buiter, Willem H., 2004, "To Purgatory and beyond: when and how should the accession countries from Central and Eastern Europe become full members of EMU?”, CEPR Discussion Paper Series, No. 4342, April, London: CEPR.

Buti, Marco and André Sapir, eds., 1998, Economic Policy in EMU, Oxford: Clarendon Press.

Cappellin, Riccardo, Enrico Marelli, Enzo Rullani and Alberto Sterlacchini, eds., 2014, Crescita, investimenti e territorio: il ruolo delle politiche industriali e regionali, Website "Scienze Regionali", eBook 2014.1, http:/www.aisre.it/ pubblicazioni/e-book (accessed November 26, 2015).

Choudhry, Misbah T., Enrico Marelli and Marcello Signorelli, 2012, "Youth Unemployment Rate and the Impact of Financial Crises", International Journal of Manpower, 33(1), pp. 76-95. http://dx.doi.org/10.1108/01437721211212538

Christiano, Lawrence, Martin Eichenbaum, and Sergio Rebelo, 2011, "When is the Government Spending Multiplier Large?", Journal of Political Economy, 119(1), pp. 78-121. http://dx.doi.org/10.1086/659312

Coenen, Günter, Roland Straub and Mathias Trabandt, 2012, "Fiscal Policy and the Great Recession in the Euro Area”, American Economic Review, Papers and Proceedings, 102(3), pp. 71-76. http://dx.doi.org/10.1257/aer.102.3.71

Corsetti, Giancarlo, 2012, "Has austerity gone too far? A new Vox Debate", VoxEU.org, http://www.voxeu.org/article/has-austerity-gone-too-far-new-voxdebate (accessed November 26, 2015). 
Dal Bianco, Silvia, Randolph Bruno and Marcello Signorelli, 2015, "The Joint Impact of Labour Policies and the "Great Recession" on Unemployment in Europe", Economic Systems, 39(1), pp. 3-26. http://dx.doi.org/10.1016/j. ecosys.2014.06.002

De Grauwe, Paul, 2007, Economics of the Monetary Union, Oxford: Oxford University Press.

De Grauwe, Paul, 2012, "How to avoid a double-dip recession in the eurozone", CEPS Commentary, November 15, 2012, https://www.ceps.eu/publications/howavoid-double-dip-recession-eurozone (accessed November 26, 2015).

European Central Bank, 2014, Unemployment in the Euro area, speech by Mario Draghi, President of the ECB, Annual Central Bank Symposium in Jackson Hole, August 22, 2014, https://www.ecb.europa.eu/press/key/date/2014/html/ sp140822.en.html (accessed November 26, 2015).

European Commission, 2012, "Report on Public Finance in EMU”, European Economy, No. 4, Brussels: European Commission.

Eichengreen, Barry J., 1993, "European Monetary Unification", Journal of Economic Literature, 31(3), pp. 1321-57.

Eurofound, 2012, NEETs - Young people not in employment, education or training: Characteristics, costs and policy responses in Europe, Luxembourg: Publications Office of the European Union.

Frankel, Jeffrey A. and Andrew K. Rose, 1998, "The endogeneity of Optimum Currency Area criteria”, Economic Journal, 108(449), pp. 1009-1025. http:// dx.doi.org/10.1111/1468-0297.00327

Frenkel, Roberto, 2013, "Lessons from a Comparative Analysis of Financial Crises", Comparative Economic Studies, 55(3), pp. 405-430. http://dx.doi. org/10.1057/ces.2013.2 
Garbellini, Nadia, Enrico Marelli and Ariel Luis Wirkierman, 2014, "Domestic demand and global production in the Eurozone: A multiregional input-output assessment of the global crisis", International Review of Applied Economics, 28(3), pp. 336-364. http://dx.doi.org/10.1080/02692171.2013.872086

Giavazzi, Francesco and Marco Pagano, 1990, "Can Severe Fiscal Contractions Be Expansionary? Tales of Two Small European Countries”, in Olivier J. Blanchard and Stanley Fischer, eds., NBER Macroeconomics Annual 1990, pp. 75-111, Cambridge, MA: MIT Press. http://dx.doi.org/10.1086/654131

Gros, Daniel, 2012, “Austerity under Attack”, Project Syndicate, February 3, 2012, http://www.project-syndicate.org/commentary/austerity-under-attack?barrier=true (accessed November 26, 2015).

Gros, Daniel and Alberto Giovannini, 2014, “The 'Relative' Importance of EMU Macroeconomic Imbalances in the Macroeconomic Imbalances Procedure", Documenti IAI, No. 14, March, Rome: Istituto Affari Internazionali.

Heyer Eric, 2012, "A review of the recent literature on fiscal multipliers: size matters!", OFCE le blog (Observatoire français des conjonctures économiques), November 21, 2012.

Higgins, Matthew and Thomas Klitgaard, 2014, "The Balance of Payments Crisis in the Euro Area Periphery", Current Issues in Economics and Finance, 20(2), pp. 1-8.

ILO, 2010, Global Employment Trends, Geneva: International Labour Organization.

ILO, 2012, Global Employment Trends, Geneva: International Labour Organization.

Imbs, Jean, 2010, “The First Global Recession in Decades," IMF Economic Review, 58(2), pp. 327-54. http://dx.doi.org/10.1057/imfer.2010.13

IMF, 2010, "Rebalancing Growth”, World Economic Outlook, April, Washington: International Monetary Fund. 
IMF, 2012, World Economic Outlook, October, Washington: International Monetary Fund.

Krugman, Paul, 1993, Lessons of Massachusetts for EMU, in Francisco Torres and Francesco Giavazzi, eds., Adjustment and Growth in the European Monetary Union, pp. 241-261, Cambridge: Cambridge University Press. http://dx.doi. org/10.1017/CBO9780511599231.016

Krugman, Paul, 2012, End this Depression Now!, New York: W. Norton \& Co.

Madrick, Jeff, 2012, "How Austerity Is Killing Europe”, The New York Review of Books, http:/www.nybooks.com/blogs/nyrblog/2012/jan/06/europe-cuttinghope/ (accessed November 26, 2015).

Marelli, Enrico, 2007, "Specialisation and convergence in European regions", The European Journal of Comparative Economics, 4(2), pp. 149-178.

Marelli, Enrico, 2014, "Quali politiche dopo la crisi?”, in Riccardo Cappellin, Enrico Marelli, Enzo Rullani and Alberto Sterlacchini, eds., Crescita, investimenti e territorio: il ruolo delle politiche industriali e regionali, Website "Scienze Regionali", eBook 2014.1, http://www.aisre.it/pubblicazioni/e-book (accessed November 26, 2015).

Marelli, Enrico, Misbah Choudhry and Marcello Signorelli, 2013, "Youth and Total Unemployment Rate: The Impact of Policies and Institutions", Rivista Internazionale di Scienze Sociali, 121(1), pp. 63-86.

Marelli, Enrico and Marcello Signorelli, 2010a, "Institutional, nominal and real convergence in Europe", Banks and Bank Systems, 5(2), pp. 41-57.

Marelli, Enrico and Marcello Signorelli, eds., 2010b, Economic Growth and Structural Features of Transition, London and New York: Palgrave-Macmillan. http://dx.doi.org/10.1057/9780230277403 
Marelli, Enrico and Marcello Signorelli, 2015, "The Eurozone crisis, the defective policy response and the need for institutional innovation”, in Theodore Eisenberg and Giovanni B. Ramello, eds., Research Handbook in Comparative Law and Economics, London: Edward Elgar, forthcoming.

Martin, Philippe, 2009, “The Geography of Inequalities in Europe”, in Gudrun Kochendorfer-Lucius and Boris Pleskovic, eds., Spatial Disparities and Development Policy, pp. 239-56, Washington D.C.: World Bank.

O’Higgins, Niall, 2012, “This Time It’s Different? Youth Labour Markets during 'The Great Recession'”, Comparative Economic Studies, 54(3), pp. 395-412. http:// dx.doi.org/10.1057/ces.2012.15

Pastore, Francesco, 2015, The Youth Experience Gap. Explaining National Differences in the School-to-Work Transition, Heidelberg: Springer Verlag.

Perotti, Roberto, 2012, “The 'Austerity Myth': Gain Without Pain?”, in Francesco Giavazzi and Alberto Alesina, eds., Fiscal Policy After the Crisis, pp. 307-354, Cambridge, MA: NBER.

Portes, Jonathan, 2012, "Self-defeating Austerity", Social Europe Journal, 31 October.

Quintini, Glenda and Thomas Manfredi, 2009, "Going Separate Ways? School-to-Work Transitions in the United States and Europe”, OECD Social, Employment and Migration Working Paper, No. 90, Paris: OECD.

Reinhart, Carmen M. and Kenneth S. Rogoff, 2009, This Time is Different: Eight Centuries of Financial Folly, Princeton: Princeton University Press.

Reinhart, Carmen M. and Kenneth S. Rogoff, 2011, "From Financial Crash to Debt Crisis", American Economic Review, 101(5), pp. 1676-1706. http://dx.doi. org/10.1257/aer.101.5.1676

Rose, Andrew, 2000, "One money, one market: the effect of common currencies on trade", Economic Policy, 15(30), pp. 7-45. http://dx.doi.org/10.1111/14680327.00056 
Roubini, Nouriel, 2010, “Double-dip days”, Project Syndicate, July 16, 2010, http:// www.project-syndicate.org/commentary/double-dip-days (accessed November 26, 2015).

Sapir, André and Guntram B. Wolff, 2015, "Euro - Area Governance: What to Reform and How to Do It?", Bruegel Policy Brief, No. 1, Brussels: Bruegel Institute, February.

Scarpetta, Stefano, Anne Sonnet and Thomas Manfredi, 2010, "Rising Youth Unemployment During the Crisis: How to Prevent Negative Long-term Consequences on a Generation?", OECD Social, Employment and Migration Working Papers, No. 6, Paris: OECD.

Schäfer, Hans-Bernd, 2012, "The Sovereign Debt Crisis in Europe, Save Banks Not States", The European Journal of Comparative Economics, 9(2), pp. 179-195. http://dx.doi.org/10.2139/ssrn.2049299

Seminerio, Mario, 2012, La cura letale, Rome and Milan: Rizzoli.

Signorelli, Marcello, Misbah T. Choudhry and Enrico Marelli, 2012, “The Impact of Financial Crises on the Female Labour", European Journal of Development Research, 24(3), pp. 413-433. http://dx.doi.org/10.1057/ejdr.2012.3

Stiglitz, Joseph E., 2012, "After Austerity", Project Syndicate, http://www.projectsyndicate.org/commentary/after-austerity (accessed November 26, 2015).

Timbeau, Xavier, 2012, “The debacle of austerity”, OFCE le blog (Observatoire français des conjonctures économiques), http://www.ofce.sciences-po.fr/blog/ the-debacle-of-austerity/ (accessed November 26, 2015).

Wyplosz, Charles, 2012a, "The coming revolt against austerity", VoxEU.org, http://www.voxeu.org/article/coming-revolt-against-austerity (accessed November 26, 2015).

Wyplosz, Charles, 2012b, "The impossible hope of an end to austerity", VoxEU.org, http://www.voxeu.org/article/impossible-hope-end-austerity (accessed November 26, 2015). 
Zingales, Luigi, 2012, "Euro, ora soldi ai disoccupati”, L'Espresso, http://espresso. repubblica.it/opinioni/libero-mercato/2012/07/09/news/euro-ora-soldi-aidisoccupati-1.44725 (accessed November 26, 2015). 